\title{
Location relative to the corpus luteum affects bovine endometrial response to a conceptus
}

\author{
Sandra Bagés-Arnal ${ }^{1}$, José M Sánchez ${ }^{1}$, Beatriz Fernandez-Fuertes ${ }^{2}$, Michael McDonald ${ }^{1}$, \\ Susanta K Behura ${ }^{3}$, Thomas E Spencer ${ }^{3}$, Trudee Fair ${ }^{1}$ and Pat Lonergan ${ }^{1}$ \\ ${ }^{1}$ School of Agriculture and Food Science, University College Dublin, Belfield, Dublin 4, Ireland, \\ ${ }^{2}$ Biotechnology of Animal and Human Reproduction (TechnoSperm), Department of Biology, Institute of \\ Food and Agricultural Technology, University of Girona, Girona, Spain and ${ }^{3}$ Division of Animal Sciences, \\ University of Missouri, Columbia, Missouri, USA
}

Correspondence should be addressed to P Lonergan; Email: pat.lonergan@ucd.ie

\begin{abstract}
In cattle, embryo transfer into the uterine horn contralateral to the corpus luteum results in a higher incidence of pregnancy loss compared to transfer into the ipsilateral horn. We have previously reported temporal changes in the endometrial transcriptome during the estrous cycle which differ between uterine horns. The objective of this study was to compare the transcriptomic response of endometrium from the ipsilateral and contralateral horns to an elongating conceptus. Cross-bred beef heifers $(n=16)$ were synchronized and either used to generate day 14 conceptuses following the transfer of in vitro-produced blastocysts or to obtain day 14 endometrial explants. Conceptuses were recovered on day 14 by post-mortem uterine flushing, placed individually on top of explants collected from the ipsilateral (IPSI-D14) or the contralateral (CONTRA-D14) uterine horn of cyclic heifers, and co-cultured for $6 \mathrm{~h}$. The response to a conceptus was markedly different between uterine horns, with 61 and 239 differentially expressed genes (DEGs; false discovery rate $<0.05$ ) in the ipsilateral and contralateral horns, respectively, compared to their controls. Direct comparison between IPSI-D1 and CONTRA-D14 revealed 32 DEGs, including CXCL11, CXCL10, IFIT2, RSAD2 and SAMD9. Gene Ontology analysis of these 32 genes revealed ten enriched biological processes, mainly related to immune response and response to an external stimulus. These data indicate that the endometrial response to the presence of a conceptus varies between uterine horns in the same uterus and may contribute to the higher incidence of pregnancy loss following embryo transfer to the contralateral horn. Reproduction (2020) 159 643-657
\end{abstract}

\section{Introduction}

Uterine receptivity in ruminants is established through spatial and temporal changes of the endometrial transcriptome and subsequent uterine luminal fluid (ULF or histotroph) composition (Lonergan \& Forde 2014). Those changes are mainly regulated by progesterone (P4) from the corpus luteum (CL) and conceptus-derived interferon tau (IFNT), which blocks the endometrial luteolytic mechanism (Forde \& Lonergan 2012, Brooks et al. 2014).

The role of $\mathrm{P} 4$ in uterine receptivity is unequivocal (Forde et al. 2009, Lonergan et al. 2016, Spencer et al. 2016). Low circulating P4 concentrations in the first week after ovulation are associated with underdeveloped conceptuses (Forde et al. 2012) with an altered transcriptomic signature (Barnwell et al. 2016) and a lower likelihood of establishing pregnancy (Diskin et al. 2006, Wiltbank et al. 2014). On the other hand, elevated concentrations of circulating P4 in the period immediately after conception have been associated with advanced conceptus elongation (Carter et al. 2008), increased IFNT production (Mann \& Lamming 2001) and, in some cases, greater pregnancy rates in cattle and sheep (Ashworth et al. 1989, Stronge et al. 2005, McNeill et al. 2006).

Endometrial tissue $\mathrm{P} 4$ concentrations are higher in the uterine horn ipsilateral to the $\mathrm{CL}$ than in the contralateral horn (Weems et al. 1988, Takahashi et al. 2016), especially during the early luteal phase (days 5 and 6) (Takahashi et al. 2016). Those differences have been associated with an increased incidence of embryo loss following transfer to the contralateral horn compared to transfer to the ipsilateral horn (Christie et al. 1979, Del Campo et al. 1983, Izaike et al. 1988), most of which occurred between days 24-42 (Christie et al. 1979).

The bovine endometrium responds differently to cloned vs IVF- or Al-derived conceptuses (Bauersachs et al. 2009, Mansouri-Attia et al. 2009), as well as to conceptuses produced in vivo or in vitro (Mathew et al. 2018) or age-matched conceptuses of different lengths (Sánchez et al. 2019). In a previous study from our 
group, we reported differential gene expression in the endometrium between the ipsilateral and contralateral horns on days $5,7,13$ and 16 of the estrous cycle (Sánchez et al. 2018), indicating that the environment in both horns is potentially different. However, whether the endometrium from the uterine horn ipsilateral or contralateral to the $\mathrm{CL}$ responds differently to an elongating conceptus is not known. Therefore, the objective of the present study was to compare the local response of the ipsilateral and contralateral endometrium to a day 14 conceptus. We hypothesized that the endometrium from the ipsilateral and contralateral uterine horns would respond differently to the presence of a conceptus, which might partly explain the reported differences in embryo loss. In order to disentangle the effect of a potentially compromised conceptus (e.g. a conceptus developed in the contralateral horn) from the effect of a compromised endometrium, conceptuses were generated under 'normal' conditions (in the horn ipsilateral to the $\mathrm{CL}$ ) and, following recovery, were placed on top of explants from either the ipsilateral or contralateral horn of cyclic heifers.

\section{Materials and methods}

All experimental procedures involving animals were approved by the Animal Research Ethics Committee of University College Dublin and licensed by the Health Products Regulatory Authority (HPRA), Ireland, in accordance with Statutory Instrument No. 543 of 2012 (under Directive 2010/63/EU on the Protection of Animals used for Scientific Purposes). Unless otherwise stated, all chemicals and reagents were sourced from Sigma-Aldrich.

\section{In vitro embryo production}

Immature cumulus-oocyte complexes (COCs) were obtained by aspirating follicles $(3-8 \mathrm{~mm})$ from the ovaries of heifers and cows collected at a local abattoir. In vitro maturation, fertilization and culture were carried out as previously described (Rizos et al. 2002). Briefly, only grade 1 and 2 COCs were selected, washed and matured for $24 \mathrm{~h}$ in $500 \mu \mathrm{L} \mathrm{TCM}$ 199 supplemented with $10 \%$ ( $\mathrm{vol} / \mathrm{vol}$ ) fetal calf serum (FCS) and $10 \mathrm{ng} / \mathrm{mL}$ EGF in groups of 50 COCs at $38.8^{\circ} \mathrm{C}$ under an atmosphere of $5 \% \mathrm{CO}_{2}$ in air with maximum humidity. Matured COCs were washed and transferred in the same groups into fertilization medium (Tyrode medium with $25 \mathrm{mM}$ bicarbonate, $22 \mathrm{mM}$ Na-lactate, $1 \mathrm{mM}$ Na-pyruvate, $6 \mathrm{mg} / \mathrm{mL}$ fatty acid-free BSA and $10 \mu \mathrm{g} / \mathrm{mL}$ heparin-sodium salt (184 U/ mg heparin; Calbiochem)) and inseminated with frozenthawed Percoll-selected bull sperm (GE Healthcare Biosciences) at a concentration of $1 \times 10^{6} \mathrm{sperm} / \mathrm{mL}$. Gametes were co-incubated at $38.8^{\circ} \mathrm{C}$ in an atmosphere of $5 \% \mathrm{CO}_{2}$ in air with maximum humidity. Approximately $20 \mathrm{~h}$ after insemination, presumptive zygotes were denuded of surrounding cumulus cells and accessory sperm by gentle vortexing, washed and transferred into $25 \mu \mathrm{L}$ droplets of culture medium (synthetic oviduct fluid supplemented with 5\% FCS) under mineral oil in groups of 25 embryos per droplet. Embryos were cultured until day 7 (day $0=$ day of in vitro fertilization) at $38.8^{\circ} \mathrm{C}$ under an atmosphere of $5 \% \mathrm{CO}_{2}, 5 \% \mathrm{O}_{2}$ and $90 \% \mathrm{~N}_{2}$ with maximum humidity.

\section{Animal model}

The experimental design is illustrated in Fig. 1A. Cross-bred beef heifers $(n=16)$ were randomly allocated to one of the following groups: embryo recipients $(n=10)$ used to generate elongated conceptuses or endometrial donors $(n=6)$ used to generate endometrial explants. The reproductive tract of all heifers was examined for normality before the experiment using a portable ultrasound machine (Easi-ScanTM; BCF Technology Ltd, Dundalk, Ireland). Heifers were synchronized as previously described by Sánchez et al. (2018) using an 8-day P4-releasing intravaginal device (PRIDRE, 1.55 g P4, Ceva Santé Animale, Libourne, France). Briefly, on the day of the PRID insertion, all animals were given $2 \mathrm{~mL}$ of a synthetic equivalent of natural gonadotrophin releasing hormone $(\mathrm{GnRH}$; Ovarelin $₫$, Ceva Santé Animale, equivalent to $100 \mu \mathrm{g}$ Gonadorelin) by i.m. injection. One day prior to PRID removal, all heifers received a $5 \mathrm{~mL}$ i.m. injection of a natural prostaglandin F2 alpha (PGF2 $\alpha$; Enzaprost $®$, Ceva Santé Animale, equivalent to $25 \mathrm{mg}$ Dinoprost) to induce luteolysis. Only those heifers observed in standing estrus $(n=14)$ were used. Day 0 was assigned as the day of the expected ovulation, which occurs approximately $28 \mathrm{~h}$ after the start of standing estrus (Walker et al. 1996, Valenza et al. 2012, Randi et al. 2018). Recipient heifers $(n=9)$ were scanned immediately before embryo transfer for assessment of $\mathrm{CL}$ size and location. On day 7, in vitro-produced blastocysts ( $n=15$ per recipient) were transferred into the ipsilateral horn. All heifers were slaughtered on day 14 to recover elongating conceptuses or endometrial tissue for explant culture. Reproductive tracts were recovered, transported to the laboratory on ice (for explants) or at ambient temperature in a polystyrene box (for conceptuses) within $2 \mathrm{~h}$ of slaughter. The uterine horns of the recipient heifers were independently flushed with PBS containing 5\% FCS. The number and dimensions (length and width) of recovered conceptuses were recorded. The endometrium of the endometrial donor heifers $(n=5)$ was processed for explants as described.

\section{Endometrial explant procedure}

Intercaruncular endometrial explants were prepared as described by Borges et al. (2012). Briefly, once at the laboratory, reproductive tracts $(n=5)$ were removed from the ice, trimmed of connective tissue and both horns were isolated. Holding the dissected end closed, the outside of each uterine horn was washed with PBS containing 1\% Antibiotic/Antimycotic (ABAM; Gibco, Thermo Fisher Scientific). Then, the horns were opened longitudinally along the anti-mesometrial side and the endometrium was washed with Hank's Balanced Salt Solution (HBSS; Gibco, Thermo Fisher Scientific) supplemented with $1 \%$ ABAM. Uterine explants $(n=4$ per heifer, i.e., two from the ipsilateral and two from the contralateral uterine horn; see Fig. 1) were removed using an $8 \mathrm{~mm}$ biopsy punch (Kruuse, Langeskov, Denmark) from the cranial third of each horn 
A Day -11

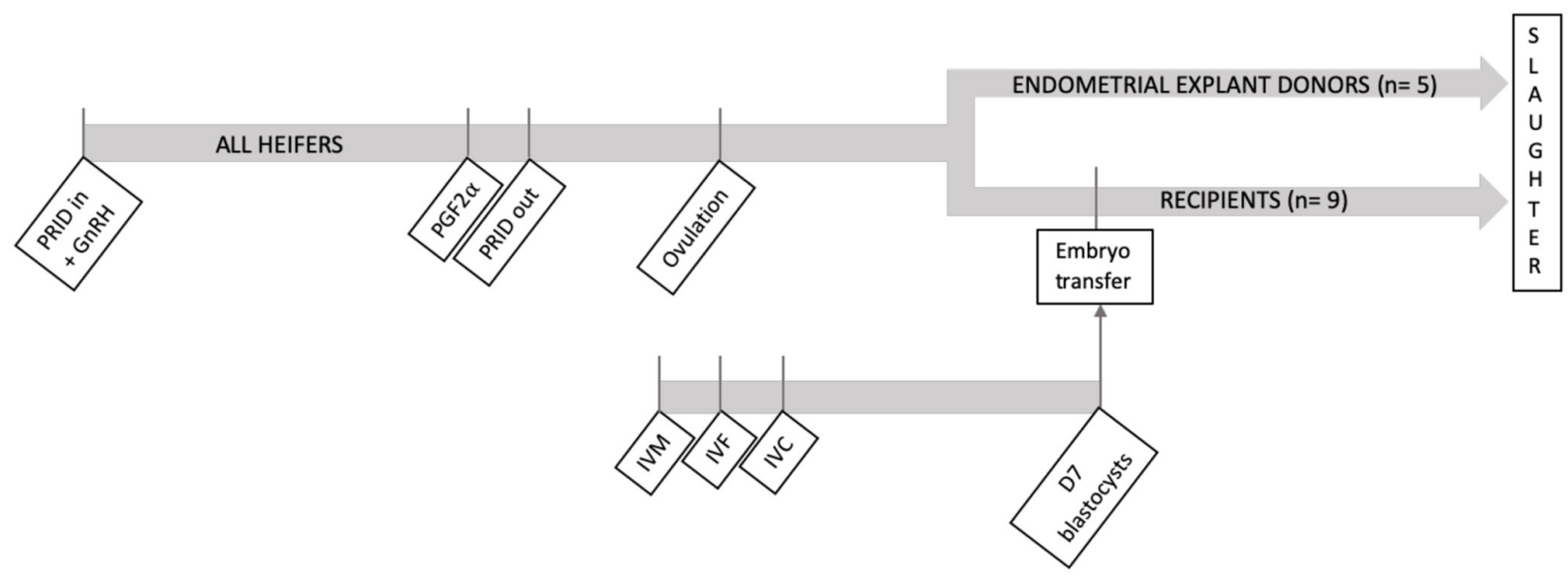

B

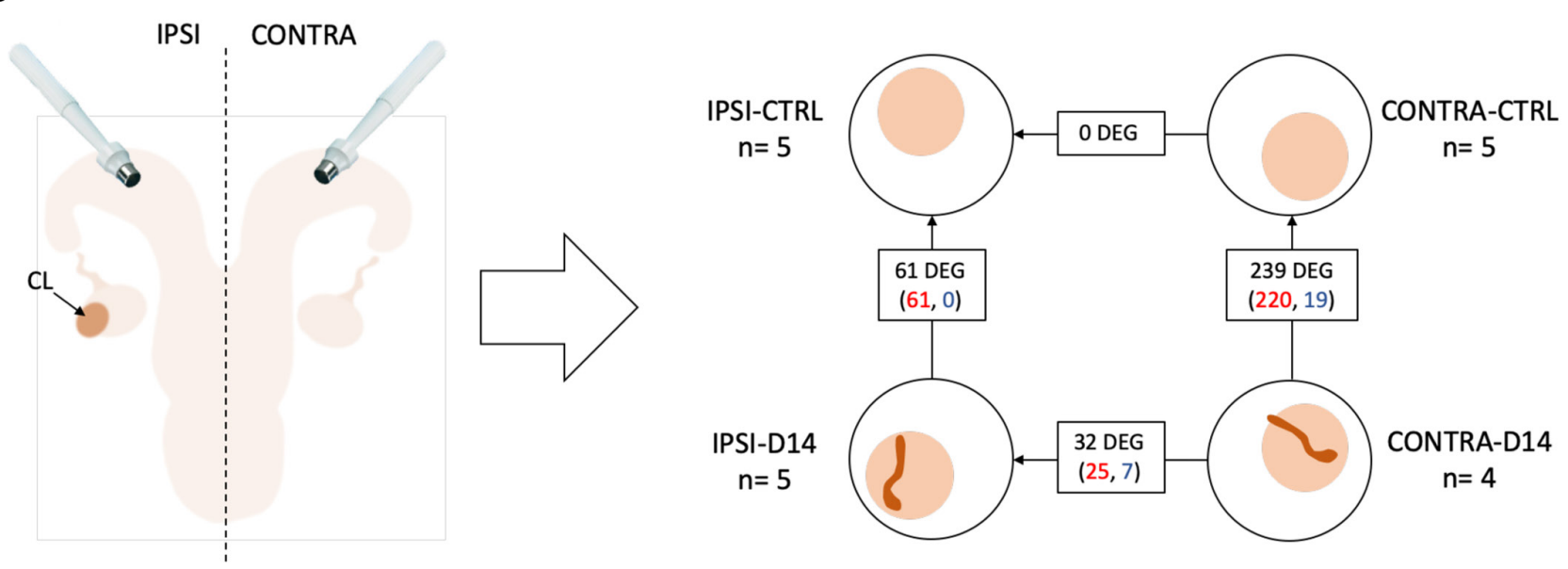

Figure 1 Experimental design: (A) synchronization protocol, in vitro embryo production and embryo transfer for the generation of day 14 conceptuses. IVM= in vitro maturation; IVF = in vitro fertilization; IVC = in vitro culture; (B) endometrial explants $(n=20)$ were recovered from the uterus of donor's heifers $(n=5)$. On the right, a summary of the experimental groups with number of replicates for each and a summary of DEGs between groups. Increased and decreased transcripts are indicated in red and blue, respectively. ${ }^{*}$ One of the explants did not have sufficient RNA quality for sequencing and was therefore removed from further analysis.

and placed into a $35-\mathrm{mm}$ dish with HBSS with $1 \%$ ABAM. The myometrium was carefully removed with a scalpel, and the explants were washed again in HBSS with $1 \%$ ABAM. Afterwards, they were transferred into the culture wells in 1 $\mathrm{mL}$ of RPMI medium (Gibco, Thermo Fisher Scientific) with $1 \% \mathrm{ABAM}$ and incubated in $5 \% \mathrm{CO}_{2}$ and air at $38.8^{\circ} \mathrm{C}$ for 1 to $4 \mathrm{~h}$ before use. At this point, the medium of all the explants was completely replaced with fresh medium. A single day 14 conceptus was placed on top of the explants from the uterine horn ipsilateral (IPSI-D14; $n=5$ ) or contralateral (CONTRA-D14; $n=5$ ) to the $\mathrm{CL}$, with the help of an insert with a $12 \mu \mathrm{M}$ pore size (Millipore). We have previously demonstrated that direct contact between the embryo and the endometrium was not necessary to detect a response of the endometrium (Passaro et al. 2018). As a control, explants from the ipsilateral (IPSI-CTRL; $n=5$ ) or contralateral (CONTRACTRL; $n=5$ ) uterine horn were incubated with medium only.
The experimental groups and replicates are summarized in Fig. 1. After $6 \mathrm{~h}$ of culture, the inserts with the conceptuses were removed and all explants were snap frozen and stored at $-80^{\circ} \mathrm{C}$ for further analysis.

\section{RNA extraction}

Total RNA extraction and purification was carried out as described by Passaro et al. (2018). Briefly, $\sim 50 \mathrm{mg}$ of endometrial tissue was homogenized in $1.0 \mathrm{~mL}$ of TRIzol (Molecular Research Center, Cincinnati, OH, USA) using a steel bead and the Qiagen tissue lyzer $(2 \times 120 \mathrm{~s}$ at maximum speed). On-column RNA purification was performed using the Qiagen RNeasy mini kit (Qiagen) as per the manufacturer's instructions. RNA was quantified using a NanoDrop-ND1000 Spectrophotometer (Thermo Fisher Scientific) and all samples were shown to a have $260 / 280 \mathrm{~nm}$ ratio greater than 1.8. RNA 
integrity number (RIN) was determined using the RNA 6000 chip on the Agilent 2100 Bioanalyzer (Agilent Technologies) and the average $R I N \pm$ s.D. was $6.62 \pm 0.3$.

\section{RNA sequencing analysis}

RNA library preparation and sequencing were conducted by the University of Missouri DNA Core Facility as previously described (Moraes et al. 2018). Briefly, libraries were constructed following the manufacturer's protocol with reagents supplied in Illumina's TruSeq Stranded mRNA Sample Prep Kit. The polyadenylated mRNA was purified from total RNA and fragmented. Double-stranded cDNA was generated from the fragmented RNA and the index-containing adapters were ligated. The final construct of each purified library was evaluated using the Fragment Analyzer instrument, quantified with the Qubit fluorimeter using the Quant-iT HS dsDNA Reagent Kit (Invitrogen) and diluted according to Illumina's standard sequencing protocol for sequencing on an Illumina NextSeq 500 sequencer. All raw and processed data from this study have been submitted to the Gene Expression Omnibus for public access.

\section{Alignment of sequences and analysis of differential gene expression}

The raw sequences (fastq) were subjected to adapter removal and quality trimming using Trimmomatic (Bolger et al. 2014). The quality reads were then mapped to the bovine reference genome ARS-UCD1.2 using Hisat2 mapper which is a fast and sensitive alignment program of next-generation sequencing data (Kim et al. 2015). The sorted binary alignment maps along with the NCBI gene annotation of the ARS-UCD1.2 assembly were subjected to FeatureCounts (Liao et al. 2014) to quantify read counts of genes for each sample. Differential expression analysis between sample groups was performed by robustly fitting the expression data to a weighted generalized linear model using edgeR robust (Zhou et al. 2014). Gene ontology (GO) was determined using DAVID (https://david.ncifcrf.gov).

\section{RNA sequencing validation using quantitative real- time PCR}

We selected nine genes to validate the RNA sequencing (RNA-seq) results with quantitative real-time PCR (qRT-PCR): interferon-induced very large GTPase 1-like (LOC783920), C-X-C motif chemokine ligand 11 (CXCL11), C-X-C motif chemokine ligand 10 (CXCL10), interferon-induced protein with tetratricopeptide repeats (IFIT)-2 (IFIT2), sterile alpha motif domain containing 9 (SAMD9), chemokine (C-C motif) ligand 8 (CCL8), cystatin E/M (CST6), radical S-adenosyl methionine domain containing 2 (RSAD2) and 2',5'-oligoadenylate synthetase 1, 40/46 kDa (OAS1Y). Genes for qRT-PCR were selected based on three criteria: being differentially expressed between at least two groups, biological significance (all interferon stimulated genes, ISGs) and fold change. Primer sequences were obtained from the literature or were designed based on Gen-Bank Ref Seq mRNA sequences using the National Center for Biotechnology Information tool, PrimerBLAST (www.ncbi.nlm.nih.gov/tools/primer-blast/) (Table 1). The protocol followed for the cDNA preparation and qRT-PCR has been previously described by Passaro et al. (2018). For each sample, cDNA was prepared from 1000 ng of total RNA using the High Capacity cDNA RT Kit (Thermo Fisher Scientific) according to the manufacturer's instructions. The purified cDNA was then diluted in RNase- and DNase-free water up to a volume of $300 \mu \mathrm{L}$. Duplicate qRT-PCR assays were performed in a total volume of $20 \mu \mathrm{L}$, containing $10 \mu \mathrm{L}$ FastStart Universal SYBR Green Master (Roche Diagnostics Ltd.), 1.2 $\mu \mathrm{L}$ forward and reverse primer mix (300 $\mathrm{nM}$ final concentration), $2.6 \mu \mathrm{L}$

Table 1 Gene symbol, accession number, primers sequence and amplicon size for all genes analyzed by quantitative real-time PCR.

\begin{tabular}{|c|c|c|c|c|}
\hline Gene symbol & Accession number & Primer sequence $\left(5^{\prime}-3^{\prime}\right)$ & Amplicon size & Reference \\
\hline LOC783920 & XM_015474717.2 & $\begin{array}{l}\text { GGATCGGCATTCCTGACTGT } \\
\text { ACTTCTCCGAGCATCTCTTGG }\end{array}$ & 112 & Primer-Blast \\
\hline CXCL11 & NM_001113173.1 & $\begin{array}{l}\text { AAGCATGAGTGTGAAGGGCA } \\
\text { ACCGTCCGCCTTTGAACATA }\end{array}$ & 92 & Primer-Blast \\
\hline CXCL10 & NM_001046551.2 & $\begin{array}{l}\text { CTGCCCACGTGTCGAGATTA } \\
\text { TGCCTCTTTCCGTGTTCGAG }\end{array}$ & 145 & Primer-Blast \\
\hline IFIT2 & XM_002698356.5 & $\begin{array}{l}\text { GAGAAGTGCACGGCAATCAT } \\
\text { TCCСTCTACCAAGTTCCAGGT }\end{array}$ & 99 & Primer-Blast \\
\hline SAMD9 & NM_001205781.2 & $\begin{array}{l}\text { TTGAATGCCTCCTACACCGA } \\
\text { CAAAGCAGCAGGGCATGAAG }\end{array}$ & 102 & Primer-Blast \\
\hline CCL8 & NM_174007.1 & $\begin{array}{l}\text { GCTGGACAGCTACACGAGAAT } \\
\text { CATCCCTGTCCGCTTTGGTC }\end{array}$ & 80 & Primer-Blast \\
\hline CST6 & NM_001012764.3 & $\begin{array}{l}\text { TGGCTGGAGACCATGTAGAC } \\
\text { TTCTTCCAGGGAACCACAAGG }\end{array}$ & 103 & Primer-Blast \\
\hline RSAD2 & NM_001045941.1 & $\begin{array}{l}\text { AACAGATAACCGCGCTCAAC } \\
\text { CTTCAAACTCCTCGTCGCTG }\end{array}$ & 129 & (Passaro et al. 2018) \\
\hline OAS1 & NM_001040606.1 & $\begin{array}{l}\text { CCCGGCGGACCCTACAGGAA } \\
\text { TCCAGCCAGACCAAAGCCGC }\end{array}$ & 84 & (Forde et al. 2011) \\
\hline RNF11 & NM_001077953.1 & $\begin{array}{l}\text { TCCGGGAGTGTGTGATCTGTATGAT } \\
\text { GCAGGAGGGGCACGTGAAGG }\end{array}$ & 131 & (Passaro et al. 2018) \\
\hline YWHAZ & NM_174814.2 & $\begin{array}{l}\text { TGAAGCCATTGCTGAACTTG } \\
\text { TCTCCTTGGGTATCCGATGT }\end{array}$ & 114 & (Passaro et al. 2018) \\
\hline
\end{tabular}


nuclease-free water and $5 \mu \mathrm{L}$ cDNA template on the ABI Prism 7500 Fast Sequence Detection System (Life Technologies, Thermo Fisher Scientific) and the appropriate positive and negative controls were included. Thermo-cycling conditions were as follows: $95^{\circ} \mathrm{C}$ for $10 \mathrm{~min}$ for one cycle, followed by $95^{\circ} \mathrm{C}$ for $15 \mathrm{~s}$ and $60^{\circ} \mathrm{C}$ for $1 \mathrm{~min}$ for 40 cycles. A dissociation curve was also added to ensure specificity of amplification. The presence of a single sharp peak in the melt curve analysis confirmed the specificity of all targets. geNorm was used to identify the most stable (average geNorm $M \leq 0.5$ ) and optimal number of reference genes (Vandesompele et al. 2002). The reference genes selected were ring finger protein 11 (RNF11) and tyrosine 3-monooxygenase/tryptophan 5-monooxygenase activation protein zeta (YWHAZ), which were subsequently used to normalize the gene expression data. A standard curve was included for each gene of interest to confirm whether primer efficiencies were between $85 \%$ and $110 \%$. The threshold cycle (Ct) for each sample was automatically calculated using the default settings within the SDS software (SDS 1.4, ABI). Ct values were imported into the qbase+ analysis package (Biogazelle, Zwijnaarde, Belgium). Data were normalized using the geometric mean of the reference genes as identified by geNorm. Relative expression values were automatically calculated by the software using a modified version of delta-delta Ct method ( $\Delta \Delta \mathrm{Cq}$; also known as $\Delta \Delta \mathrm{CT})$ (Hellemans et al. 2008). One-way ANOVA was performed on the log transformed data.

\section{Results}

\section{Conceptus recovery}

Day 14 conceptuses were recovered from seven out of the nine $(77.7 \%)$ recipient heifers. The recovery rate (proportion of conceptuses recovered relative to the number transferred) was 51.8\% (70/135). The mean length of the recovered conceptuses was $11.32 \pm 1.34$ $\mathrm{mm}$ (mean \pm S.E.M.). Only intact filamentous conceptuses with a length between 10 and $20 \mathrm{~mm}$ were individually co-cultured on top of the endometrial explants $(n=10$ conceptuses, mean length $14.58 \pm 0.73 \mathrm{~mm}$ ).

\section{RNA sequencing and gene ontology analysis}

One of the explants in the CONTRA-D14 group was of insufficient quality for RNA-seq and was therefore removed from further analysis. The RNA-seq of the remaining uterine explants $(n=19)$ generated an average of 39.3 million reads per sample. The average mapping rate per sample was $96.2 \%$. The number of differentially expressed genes (DEGs) and the status of expression (up- or down-regulated) is summarized in Fig. 1B. There were no differences between the transcriptome of the IPSI-CTRL and CONTRA-CTRL endometrial explants. However, the response of the ipsilateral and contralateral endometrium to a day 14 conceptus was remarkably different. Analysis of the RNA-seq data revealed 61 DEGs (all upregulated, based on false discovery rate (FDR) <0.05, Supplementary Table 1, see section on supplementary materials given at the end of this article) between IPSI-D14 and IPSI-CTRL and 239 DEGs (220 upregulated, 19 downregulated; Supplementary Table 2) between CONTRA-D14 and CONTRA-CTRL. Further, the comparison of these sets of DEGs revealed that 54 transcripts were upregulated in both experimental groups, while 7 and 185 were unique to IPSI-D14 and CONTRA-D14, respectively (Fig. 2).

The majority of the top upregulated genes by a D14 conceptus that were shared between groups were typical ISGs (16 out of the top 20, see Table 2). These included: RSAD2, MX dynamin like GTPase 2 (MX2), interferon-induced protein with tetratricopeptide repeats 1 (LOC100139670), IFIT3, C-type lectin domain family 4 member $F(C L E C 4 F)$, interferon-induced protein 44 (IFI44), ISG15 ubiquitin-like modifier (ISG15), IFIT2, 2',5'-oligoadenylate synthetase 1, 40/46 kDa (OAS1Z) and CCL8.

GO analysis of the 61 DEGs between IPSI-D14 and IPSI-CTRL identified 39 enriched biological processes (BP) $(P \leq 0.05$; Supplementary Table 3$)$. The top five BP include: (1.) response to interferon-alpha (IFNA), (2.) cytoplasmic pattern recognition receptor signaling

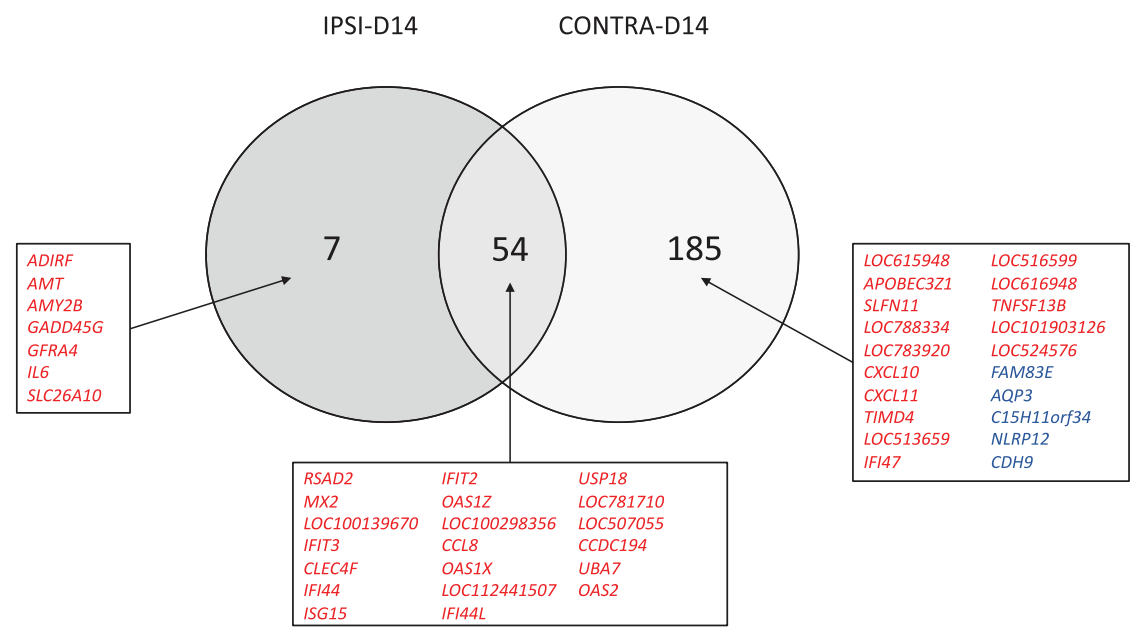

Figure 2 Venn diagram (Venny 2.1.0 BioinfoGP) showing the number of unique or common differentially expressed genes (DEGs) between endometrial explants of uterine horns ipsilateral and contralateral to the corpus luteum following exposure to a day 14 conceptus (IPSI-D14 and CONTRA-D14). DEGs were previously determined in each group relative to the respective controls. Increased and decreased transcripts are indicated in red and blue, respectively. 
Table 2 Top 20 genes upregulated in both ipsilateral and contralateral endometrium exposed to a day 14 conceptus (IPSI-D14 and CONTRA-D14, respectively).

\begin{tabular}{|c|c|c|c|c|}
\hline Gene symbol & Gene description & $\begin{array}{c}\log \text { FC } \\
\text { IPSI-D14 }\end{array}$ & $\begin{array}{c}\log \text { FC } \\
\text { CONTRA-D14 }\end{array}$ & $\begin{array}{l}\text { FDR IPSI-D14 vs } \\
\text { CONTRA-D14 }\end{array}$ \\
\hline RSAD2 & radical S-adenosyl methionine domain containing 2 & 5.63 & 8.03 & $<0.05$ \\
\hline MX2 & MX dynamin like GTPase 2 & 5.84 & 7.81 & 0.148 \\
\hline LOC100139670 & interferon-induced protein with tetratricopeptide repeats 1 & 5.30 & 6.90 & $<0.05$ \\
\hline IFIT3 & interferon-induced protein with tetratricopeptide repeats 3 & 5.20 & 6.36 & 0.227 \\
\hline CLEC4F & C-type lectin domain family 4 member $F$ & 6.72 & 4.30 & 0.906 \\
\hline IFI44 & interferon-induced protein 44 & 5.00 & 5.81 & 0.142 \\
\hline ISG15 & ISG15 ubiquitin-like modifier & 4.39 & 5.66 & 0.286 \\
\hline IFIT2 & interferon-induced protein with tetratricopeptide repeats 2 & 3.97 & 5.56 & $<0.05$ \\
\hline OAS1Z & $2^{\prime}, 5^{\prime}$-oligoadenylate synthetase $1,40 / 46 \mathrm{kDa}$ & 3.69 & 5.06 & 0.051 \\
\hline LOC100298356 & bone marrow stromal antigen 2 & 3.56 & 5.19 & 0.185 \\
\hline CCL8 & chemokine (C-C motif) ligand 8 & 3.37 & 5.36 & $<0.05$ \\
\hline OAS1X & $2^{\prime}, 5^{\prime}$-oligoadenylate synthetase $1,40 / 46 \mathrm{kDa}$ & 3.42 & 5.00 & 0.467 \\
\hline LOC112441507 & bone marrow stromal antigen 2-like & 3.42 & 4.97 & 0.071 \\
\hline IFI44L & interferon-induced protein 44 like & 3.81 & 4.41 & 0.521 \\
\hline USP18 & ubiquitin specific peptidase 18 & 3.28 & 4.88 & $<0.05$ \\
\hline LOC781710 & guanylate-binding protein 2 & 2.95 & 4.73 & 0.400 \\
\hline LOC507055 & guanylate-binding protein 4 & 2.73 & 4.86 & $<0.05$ \\
\hline CCDC194 & coiled-coil domain containing 194 & 3.04 & 4.55 & 0.489 \\
\hline UBA7 & ubiquitin like modifier activating enzyme 7 & 3.00 & 4.39 & 0.228 \\
\hline OAS2 & $2^{\prime}-5^{\prime}$-oligoadenylate synthetase 2 & 3.19 & 4.19 & 0.286 \\
\hline
\end{tabular}

Logarithm of fold change (Log FC) relative to its respective controls. False discovery rate (FDR) from the direct comparison between IPSI-D14 vs CONTRA-D14; FDR $<0.05$ means they are differentially expressed. For full list of DEGs, see Supplementary Tables 1, 2 and 5.

pathway, (3.) negative regulation of viral genome replication, (4.) positive regulation of response to cytokine stimulus and (5.) negative regulation of viral life cycle. For the contralateral uterine horn, the GO analysis of the 239 DEGs between the CONTRA-D14 and CONTRACTRL group identified 87 enriched BP (Supplementary Table 4), including: (1.) interferon-gamma (IFNG)mediated signaling pathway, (2.) response to type I interferons (IFNs), (3.) regulation of IFNA production, (4.) negative regulation of viral genome replication and (5.) positive regulation of IFNA production.

The direct comparison of RNA-seq data from IPSI-D14 vs CONTRA-D14 identified 32 DEGs (25 upregulated, 7 downregulated; Supplementary Table 5). The ten most upregulated genes (greatest to least) in CONTRA-D14 relative to IPSI-D14 included: LOC783920, CXCL11, CXCL10, IFIT2, RSAD2, SAMD9, guanylate-binding protein 4 (LOC507055), CD274 molecule (CD274), cytidine/UMP kinase 2 (CMPK2) and LOC100139670. The seven down-regulated genes (from most downregulated to least) were: lipopolysaccharide binding protein (LBP), AQP3, CST6, SEM1 26S Proteasome Complex Subunit (SEM1), S100 calcium binding protein A2 (S100A2), microfibril associated protein 2 (MFAP2) and plexin A3 (PLXNA3).

GO analysis of the 32 DEGs between IPSI-D14 and CONTRA-D14 identified ten enriched BP(Supplementary Table 6): (1.) positive regulation of cAMP-mediated signaling, (2.) regulation of innate immune response, (3.) defense response to other organism, (4.) positive regulation of cytokine production, (5.) immune effector process, (6.) response to other organism, (7.) response to external biotic stimulus, (8.) response to biotic stimulus, (9.) regulation of immune system process and (10.) response to external stimulus.

\section{qRT-PCR validation of $R N A$-seq results}

Using qRT-PCR, nine genes of interest (LOC783920, CXCL11, CXCL10, IFIT2, SAMD9, CCL8, CST6, RSAD2 and OAS1Y) were validated in all groups (four comparisons for each gene). Thirty of the 36 comparisons $(83.3 \%)$ were in agreement between RNA-seq and qRT$\mathrm{PCR}$, that is, one gene was found to be differentially expressed, or not, between two groups in both analyses. Although qRT-PCR failed to detect a significant difference among six of the comparisons that were found to be differentially expressed in the RNA-seq, the trend (e.g. upregulated in CONTRA-D14 compared to CONTRACTRL) was always consistent (Fig. 3 and Table 3).

\section{Discussion}

In order to understand the lower pregnancy rates observed following embryo transfer to the contralateral uterine horn, this study aimed to compare the local response of bovine endometrium ipsilateral and contralateral to the $\mathrm{CL}$ to an elongating conceptus. In order to disentangle the effect of a potentially compromised embryo/conceptus from the effect of a compromised endometrium, conceptuses were generated under 'normal' conditions (in the horn ipsilateral to the $\mathrm{CL}$ ) and placed on top of endometrial explants from either the ipsilateral or contralateral horn. Major findings 

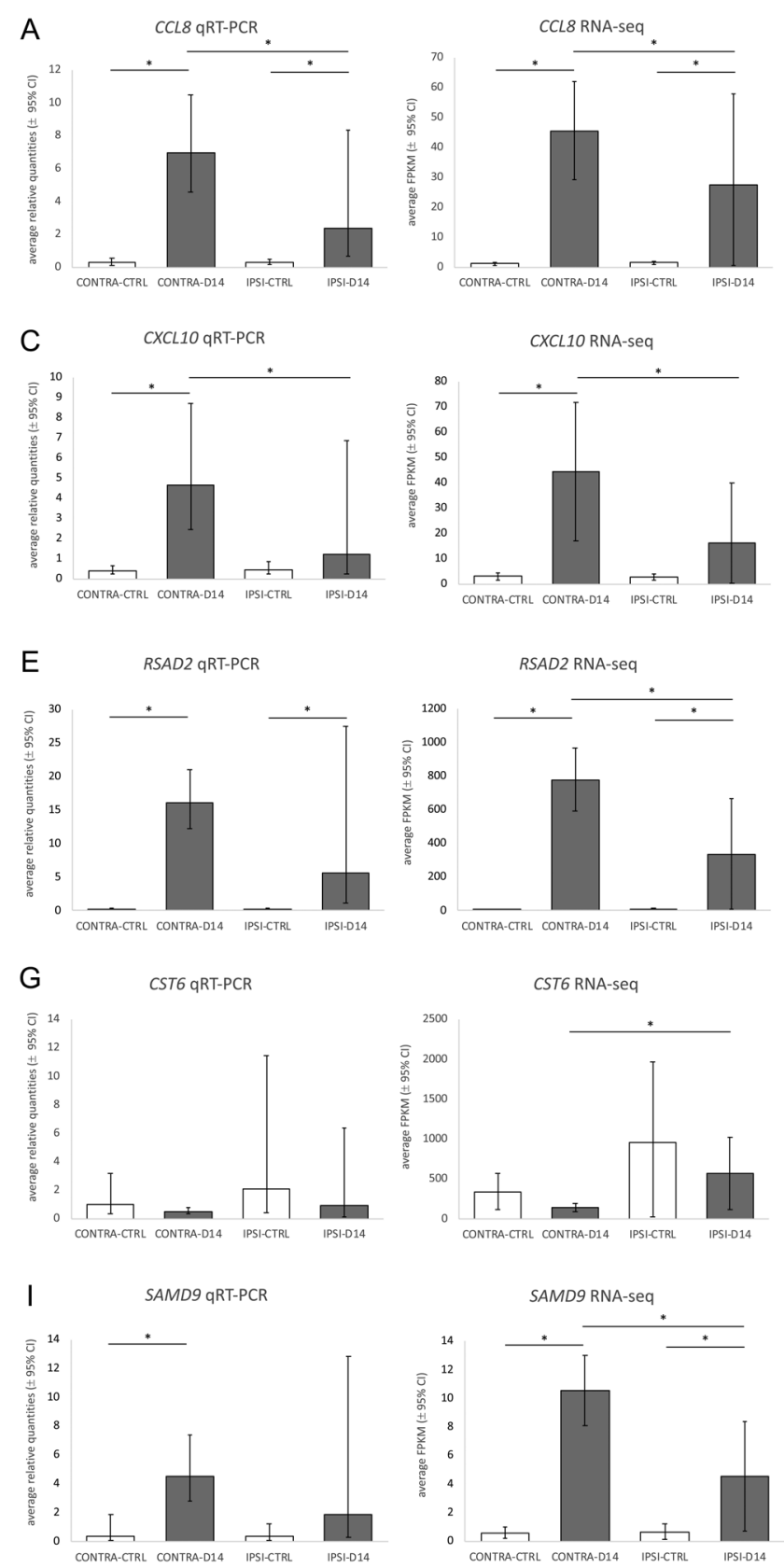
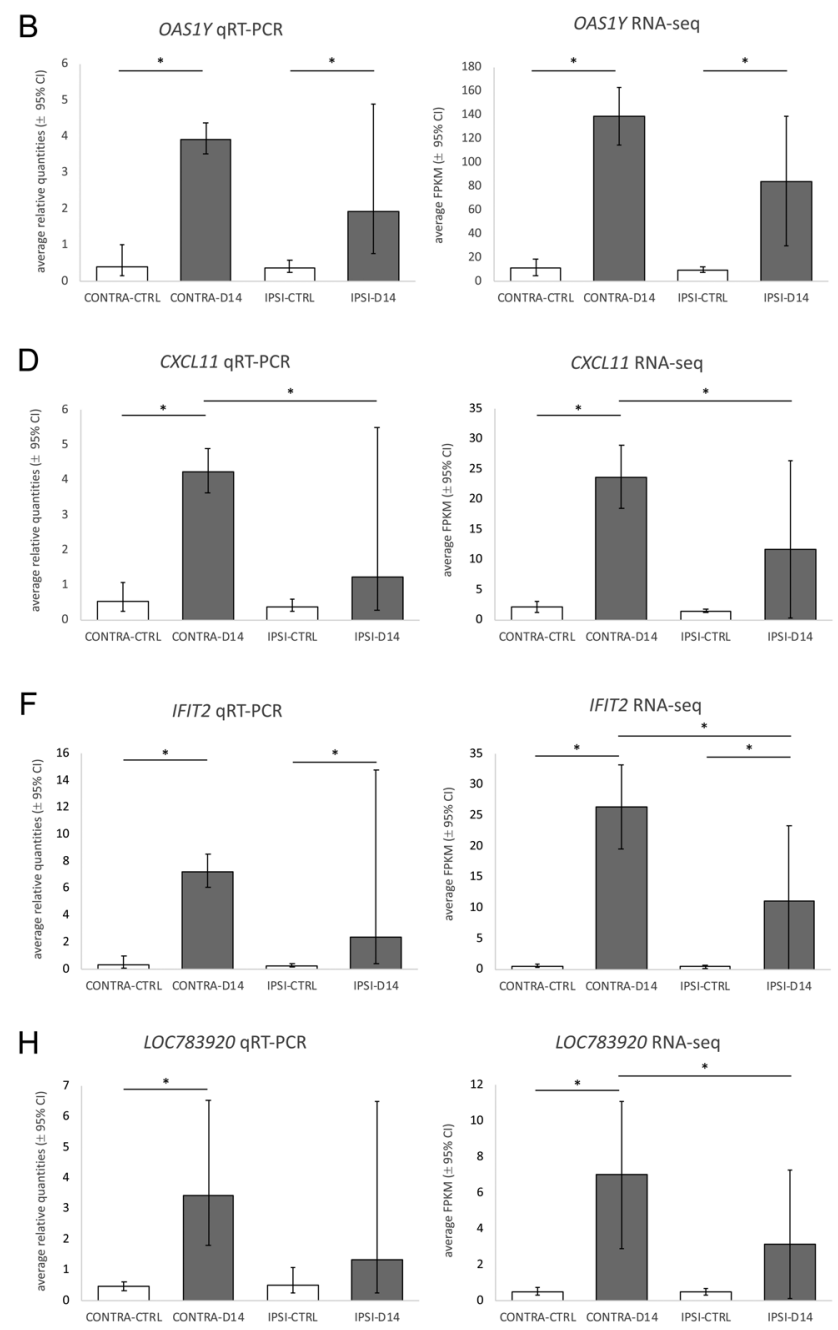

Figure 3 Comparison between quantitative real-time PCR (qRT-PCR) and RNA sequencing (RNA-seq) data for nine selected genes. Note that for 4 of the 9 genes (A to D), all comparisons are in agreement; while the qRT-PCR failed to detect a significant difference in transcript abundance in some comparisons from the other 5 genes (E to I) the trend was always consistent.

from this study are: (1.) although no differences in gene expression were detected between IPSI-CTRL and CONTRA-CTRL (i.e. non-pregnant) endometrium, the response of the endometrium to a day 14 conceptus was distinct in each uterine horn; (2.) interestingly, more genes were differentially expressed in the contralateral than in the ipsilateral endometrium after exposure to a conceptus and (3.) many of the biological processes enriched in the DEGs between CONTRA-D14 and IPSI-D14 are associated with immune response and response to stimuli. These data extend the results of Sánchez et al. (2018) who described temporal changes in the transcriptome of the endometrium ipsilateral and contralateral to the CL by describing differential response of the endometrium in both uterine horns to an elongating conceptus.

In terms of the relevancy of the model, while it is true that, in commercial practice, most single embryo transfer is done into the ipsilateral horn, there are occasions when it may be done deliberately into the 
Table 3 Summary of RNA sequencing (RNA-seq) results validation through quantitative real-time PCR (qRT-PCR).

\begin{tabular}{|c|c|c|c|}
\hline Comparisons & RNA-seq & qRT-PCR & $\begin{array}{c}\text { Log FC } \\
\text { RNA-seq }\end{array}$ \\
\hline \multicolumn{4}{|l|}{ RSAD2 } \\
\hline IPSI-CTRL vs IPSI-D14 & YES & YES & 5.63 \\
\hline IPSI-CTRL vs CONTRA-CTRL & NO & NO & \\
\hline IPSI-D14 vs CONTRA-D14 & YES & NO & 1.98 \\
\hline CONTRA-CTRL vs CONTRA-D14 & YES & YES & 8.03 \\
\hline \multicolumn{4}{|l|}{ OAS1Y } \\
\hline IPSI-CTRL vs IPSI-D14 & YES & YES & 2.87 \\
\hline IPSI-CTRL vs CONTRA-CTRL & NO & NO & \\
\hline IPSI-D14 vs CONTRA-D14 & $\mathrm{NO}$ & NO & \\
\hline CONTRA-CTRL vs CONTRA-D14 & YES & YES & 3.82 \\
\hline \multicolumn{4}{|l|}{ CXCL10 } \\
\hline IPSI-CTRL vs IPSI-D14 & NO & $\mathrm{NO}$ & \\
\hline IPSI-CTRL vs CONTRA-CTRL & NO & NO & \\
\hline IPSI-D14 vs CONTRA-D14 & YES & YES & 2.16 \\
\hline CONTRA-CTRL vs CONTRA-D14 & YES & YES & 3.75 \\
\hline \multicolumn{4}{|l|}{ IFIT2 } \\
\hline IPSI-CTRL vs IPSI-D14 & YES & YES & 3.97 \\
\hline IPSI-CTRL vs CONTRA-CTRL & NO & NO & \\
\hline IPSI-D14 vs CONTRA-D14 & YES & NO & 2.04 \\
\hline CONTRA-CTRL vs CONTRA-D14 & YES & YES & 5.56 \\
\hline \multicolumn{4}{|l|}{ LOC783920 } \\
\hline IPSI-CTRL vs IPSI-D14 & NO & NO & \\
\hline IPSI-CTRL vs CONTRA-CTRL & NO & NO & \\
\hline IPSI-D14 vs CONTRA-D14 & YES & NO & 2.42 \\
\hline CONTRA-CTRL vs CONTRA-D14 & YES & YES & 3.84 \\
\hline \multicolumn{4}{|l|}{ SAMD9 } \\
\hline IPSI-CTRL vs IPSI-D14 & YES & NO & 2.87 \\
\hline IPSI-CTRL vs CONTRA-CTRL & NO & NO & \\
\hline IPSI-D14 vs CONTRA-D14 & YES & NO & 1.81 \\
\hline CONTRA-CTRL vs CONTRA-D14 & YES & YES & 4.39 \\
\hline \multicolumn{4}{|l|}{ CST6 } \\
\hline IPSI-CTRL vs IPSI-D14 & NO & NO & \\
\hline IPSI-CTRL vs CONTRA-CTRL & NO & NO & \\
\hline IPSI-D14 vs CONTRA-D14 & YES & NO & -1.84 \\
\hline CONTRA-CTRL vs CONTRA-D14 & NO & NO & \\
\hline \multicolumn{4}{|l|}{ CXCL11 } \\
\hline IPSI-CTRL vs IPSI-D14 & NO & NO & \\
\hline IPSI-CTRL vs CONTRA-CTRL & NO & NO & \\
\hline IPSI-D14 vs CONTRA-D14 & YES & YES & 2.21 \\
\hline CONTRA-CTRL vs CONTRA-D14 & YES & YES & 3.51 \\
\hline \multicolumn{4}{|l|}{ CCL8 } \\
\hline IPSI-CTRL vs IPSI-D14 & YES & YES & 3.37 \\
\hline IPSI-CTRL vs CONTRA-CTRL & NO & NO & \\
\hline IPSI-D14 vs CONTRA-D14 & YES & YES & 1.67 \\
\hline CONTRA-CTRL vs CONTRA-D14 & YES & YES & 5.36 \\
\hline
\end{tabular}

'YES' or 'NO' refers whether the gene expression was found significantly different for each of the comparisons or not. 'Log FC RNA-seq' refers to the logarithm of fold change (Log FC) of the second group relative to the first (i.e. IPSI-D14 relative to IPSI-CTRL for the first comparison) for the RNA-seq data.

contralateral horn or when an embryo can find itself in that horn. One such scenario is in the beef industry where, in order to induce twins to increase efficiency, an embryo may be transferred to the contralateral horn of a female which had been bred by $\mathrm{Al}$ at oestrus 7 days earlier (or two embryos may be bilaterally transferred). (Sreenan et al. 1981, Sreenan \& Diskin 1989, GuerraMartinez et al. 1990, Dahlen et al. 2012). Coupled with poor profitability of the sector and increasing focus on its carbon footprint, the future sustainability of beef cow herds in some countries, including Ireland, is under pressure. Twinning, along with improvements in genetic gain through use of selected sires, offers the potential to increase output, profitability and reduce greenhouse gas emissions due to increased output and a dilution in overhead costs per animal. Furthermore, results from the long-term twinning project at the US Meat Animal Research Center (USMARC), Clay Center, Nebraska, where the frequency of fraternal twin births increased from $3.1 \%$ to $>50 \%$ per year in about 20 years through selection, indicate that dams producing twins weaned $70.8 \%$ more calves than dams with a single birth (Echternkamp \& Gregory 2002).

A second scenario in which the embryo may end up in the contralateral horn is due to transuterine migration. The incidence of transuterine migration is low in cattle following fertilization in vivo by natural mating or Al (about $10 \%$ based on studies by Rowson et al. 1971, Scanlon 1972). When two ovulations occurred in the same ovary and two foetuses were present, $20 \%$ of cows had evidence of transuterine migration (Scanlon 1972). Importantly, however, transuterine migration is significantly higher following embryo transfer, particularly when more than one embryo is transferred. Several studies have reported an increase in the incidence of migration when more than one embryo was initially located in the same uterine horn (Scanlon 1972, McMillan \& Peterson 1995, 1999). In the study by McMillan and Peterson (1995), following the uni-lateral transfer of two embryos, more than half of all twin pregnancies were bilateral (23/38, 61\%). Thirdly, although perhaps less relevant, but nonetheless noteworthy is the fact that, nowadays, a high proportion of double ovulations occur in high-producing dairy cows. In one study, the incidence of double ovulation was nearly three-fold greater for high $(20.2 \%)$ vs low $(6.9 \%)$ milk producing cows (Fricke \& Wiltbank 1999). Clearly, if ovulations occur bilaterally, then each horn is essentially ipsilateral to a CL; however, where they occur unilaterally, in a small number of cases one embryo may end up in the contralateral horn. Surprisingly, there are very few data available describing the proportion of such cows that go on to deliver twins. Garcia-Ispierto and López-Gatius (2019) examined the incidence and timing of abortion in Holstein Friesian dairy cows with advanced twin pregnancies in north-eastern Spain. From 1194 twin pregnancies at around Day 60 (522 bilateral and 672 unilateral), abortion was recorded in 278 $(23.3 \%)$ cows before Day 260 of pregnancy: 7 (1.3\%) in bilateral and $271(40.3 \%)$ in unilateral twin pregnancies.

Another point to consider is the possibility that the response of an endometrial explant from the uterine horn contralateral to $C L$ to a conceptus which developed in the uterine horn ipsilateral to CL may not be same as that to a conceptus developed in the contralateral horn. 
While this is a possibility, as mentioned previously, the design used here allows the disentangle of the effect of a potentially compromised embryo from the effect of a compromised endometrium. There is very little evidence to indicate that there is any meaningful response from the endometrium to the presence of a conceptus before Day 7 (the day on which the embryos were transferred in this study). Many studies from our own group (Forde et al. 2011) as well as others (Bauersachs et al. 2012) have demonstrated that no transcriptomic response is detectable from the endometrium prior to Day $15 / 16$. This is entirely consistent with what occurs in commercial embryo transfer practice, where embryos, typically on Day 7, are transferred into the uterus of a synchronised recipient which has had no pre-exposure to an embryo or products derived therefrom.

In two recent studies from our group, we have clearly demonstrated that, using an explant model such as that described in this study, it is possible to detect subtle embryo-induced changes in the endometrial transcriptome (Passaro et al. 2018, 2019). This was only possible by placing multiple blastocysts on top of explants and by being able to analyse the tissue that was directly below the embryos. Interesting, all of the genes altered in the endometrium were IFNT-related, as conformed by comparison with the response of endometrial tissue to stimulation with recombinant IFNT or Day 15 conceptuses (Sánchez et al. 2019).

In a previous study from our group (Sánchez et al. 2018), we compared the transcriptome of the endometrium ipsilateral and contralateral to the $C L$ in cyclic heifers at four different time points: day 5, 7, 13 and 16. The number of DEGs was highest on day 5 (217 DEGs) and progressively decreased with time (54, 14 and 18 DEGs, respectively) (Sánchez et al. 2018). Consistent with these results, in the present study, we did not detect any differences between the non-pregnant ipsilateral and contralateral (IPSI-CTRL vs CONTRA-CTRL) endometrial transcriptome on day 14 . The slight difference between the two studies (14 DEGs on day 13 in Sánchez et al. 2018 and none on day 14 in the present study) could be due to the difference in sample type; in the first case, samples were intercaruncular endometrial strips collected and snap frozen immediately after slaughter, while in the current study, samples were endometrial explants collected after slaughter and incubated for 7 to $10 \mathrm{~h}$ before being snap frozen.

Despite the lack of differences in the endometrial transcriptome between the IPSI-CTRL and CONTRACTRL samples, the response of the endometrium to a day 14 conceptus was substantially different between uterine horns. The number of altered genes due to the presence of a conceptus was almost four-fold higher in the CONTRA-D14 compared to IPSI-D14 (239 vs 61 DEGs, respectively). This observation is consistent with the study of Moraes et al. (2018), where relatively few differences were detected in the endometrial transcriptome of non-pregnant high-fertile, subfertile and infertile heifers; however, the response of the endometrium from high-fertile and subfertile animals to pregnancy was remarkably different (3422 vs 1095 DEGs, respectively).

\section{Endometrial response to a day 14 conceptus in the IPSILATERAL uterine horn}

Most of the DEGs in the ipsilateral horn exposed to a conceptus were also differentially expressed in the contralateral endometrium (54 out of 61). Only seven genes were uniquely upregulated in the ipsilateral horn (Fig. 2): adipogenesis regulatory factor (ADIRF), aminomethyltransferase $(A M T)$, amylase, alpha 2B (pancreatic) $(A M Y 2 B)$, growth arrest and DNA damage inducible gamma (GADD45G), GDNF family receptor alpha 4 (GFRA4), interleukin 6 (IL6) and solute carrier family 26 member 10 (SLC26A10).

$A M T$ gene expression has been previously reported as being more abundant in endometrial explants from pregnant than cyclic and/or uterine gland knockout (UGKO) sheep on day 14 (Gray 2005). AMT is part of the glycine cleavage system (Okamura-lkeda et al. 2010), which produces 5,10-methylenetetrahydrofolate as a donor of one-carbon units, which is essential for the synthesis of DNA during cell proliferation (Fleming \& Copp 1998). Glycine is one of the most abundant amino acids in the ULF of cyclic and pregnant heifers (Groebner et al. 2011, Forde et al. 2014b) and sheep (Gao et al. 2009). On day 15 , pregnant heifers had higher levels of glycine than cyclic heifers (Groebner et al. 2011), which could explain a higher AMT gene expression in IPSI-D14 compared to IPSI-CTRL. This gene could be important for the support of conceptus growth and development due to its role in DNA synthesis.

SLC26A10 belongs to a family of anion transporters expressed in many epithelia (Ohana et al. 2009). Members of the solute carrier family 26 (SLC26) are responsible for regulating the ULF $\mathrm{pH}$, secreting bicarbonate into the lumen in exchange for the luminal chlorine, which is in turn is secreted via the cystic fibrosis transmembrane conductance regulator (CFTR) (Xie et al. 2018). Interestingly, CFTR is one of the top ten downregulated genes in CONTRA-D14 relative to its control. The acid-base homeostasis in the reproductive tract is critically important for reproduction (Xie et al. 2018). The different expression of genes related to $\mathrm{pH}$ balance could reflect differences in the ULF pH between the uterine horns, making the contralateral a less favorable environment for embryo development and implantation.

In agreement with our results, IL6 was found to be upregulated in a previous study from our group in which endometrial explants were exposed to a day 15 conceptus compared with the controls and explants treated with IFNT (Mathew et al. 2018). IL6 encodes a cytokine that has both pro-inflammatory and anti- 
inflammatory activities and is a major player in the regulation of the acute phase response and immune response (Heinrich et al. 1990, Scheller et al. 2011). One of the functions of IL6 is coordinating the balance of T cell phenotypes (Prins et al. 2012). T-helper (Th) cells are required for almost all adaptive immune responses and can differentiate into several distinct subtypes, including Th1, Th2, Th17 and T regulatory (Tregs) cells (Oliveira et al. 2013). Th1 and Th17 play a central role in the induction of inflammation and are involved in the allograft rejection process (Alberts et al. 2002, Saini et al. 2011). In contrast, Th2 and Treg are crucial for the induction and the maintenance of allograft tolerance (Saini et al. 2011). IL6 is a very important factor in determining Th17/Treg balance, promoting the generation of Th17 and inhibiting Treg differentiation (reviewed by Kimura \& Kishimoto 2010).

Pregnancy requires a delicate balance between pro-inflammatory and anti-inflammatory molecules to maintain maternal immune system integrity while preventing rejection of the embryo (Walker et al. 2010, Mansouri-Attia et al. 2012). In humans, both IL6 deficiency and IL6 excess have been linked with reproductive impairment (Prins et al. 2012). Il6 null mutant mice exhibit normal estrous cycles, ovulation, fertilization and embryo implantation, but frequent occurrence of fetal resorption in mid-gestation (Robertson 2010). Although the mechanisms underlying fetal loss in the absence of IL6 are not defined (Prins et al. 2012), the fact that IL6 is exclusively upregulated in the IPSI-D14 and not in the CONTRA-D14 may suggest an imbalance in the T cell population that could lead to a loss of pregnancy in a more advance stage. This notion would be consistent with the observations from Christie et al. (1979) that a great number of developing embryos died between days 24-42 when transfers were done into the contralateral horn.

Regarding the GO analysis of these 61 DEGs between IPSI-D14 and IPSI-CTRL, only 2 of the 39 enriched $\mathrm{BP}$ were exclusive to the ipsilateral endometrium: response to IFNA (GO:0035455) and cytoplasmic pattern recognition receptor (PRRs) signaling pathway (GO:0002753). Interestingly, those were the ones with highest fold enrichment (over 100). Both BP are somewhat related to the immune response. In the first case, IFNA is an important antiviral cytokine quite similar to IFNT $(\sim 50 \%$ identity) and with similar biological activities (Green et al. 2005, Bauersachs et al. 2012). It is secreted mainly by plasmacytoid dendritic cells and serves to alert cells of both innate and adaptive immunity to the threat of infections (reviewed by Huber \& Farrar 2011). In addition, it ensures the proper differentiation of Th1 cells by restricting the development of alternative subsets like Th2 and Th17 (Huber \& Farrar 2011). In the second case, toll-like receptors (TLRs), a type of PRRs, are one of the main regulators of innate immunity and are key regulators in immunologic events during stages of normal pregnancy such as implantation (reviewed by
Amirchaghmaghi et al. 2013). These two BP uniquely enriched in the ipsilateral endometrium suggest that the immune response to a conceptus is different between uterine horns.

Overall, analysis of the unique DEG and BP in the ipsilateral uterine horn suggests that a favorable environment includes support of conceptus growth and development $(A M T)$, an appropriate regulation of ULF homeostasis (SLC26A10 - CFTR) and a balanced immune response (IL6, GO:0035455, GO:0002753).

\section{Endometrial response to a day 14 conceptus in the CONTRALATERAL uterine horn}

Comparison between CONTRA-D14 and its control revealed 239 DEGs, 185 of which were differentially expressed uniquely in the contralateral uterine horn. Of those 185 genes, Schlafen Family Member 11 (SLFN11), CXCL10, CXCL11 and T cell immunoglobulin and mucin domain containing 4 (TIMD4) were among the top ten upregulated. The major function of chemokines, such as CXCL10 and CXCL11, is to recruit immune cells including leukocytes, lymphocytes and macrophages to inflammatory regions (Janeway \& Medzhitov 2002). Furthermore, it has been hypothesized that endometrial chemokines may regulate conceptus adhesion to the uterine epithelium due to the expression of chemokine receptors not only in the endometrium but also in trophoblast cells from mice, goats and sheep (Dominguez et al. 2003, Nagaoka et al. 2003, Imakawa et al. 2006). Chemokines CXCL10 and CXCL11 were expressed during the peri-implantation period (from day 14 to 20) in ovine endometrium; expression of both factors increased as implantation advanced, with maximum expression on day 17 for CXCL11 and on day 20 for CXCL10 (Imakawa et al. 2006).

TIMD4 serves as the natural ligand for $\mathrm{T}$ cell immunoglobulin and mucin domain (TIM)-1, another protein of the TIM family, and this interaction is necessary for T cell proliferation (Umetsu et al. 2005). The TIM family is involved in modulating host immune responses likely by altering the Th1/Th2 balance (Jones 2002). SLFN11 is an inhibitor of DNA replication that promotes cell death in response to DNA damage (Zoppoli et al. 2012). In mammals, preparation of the uterus for implantation includes endometrial tissue remodeling, including cell death (Tassell et al. 2000, Liu et al. 2005, Okano et al. 2007). However, the expression profile of cell death-related genes in the bovine pregnant uterus still remains unverified (Suzuki et al. 2018).

SLFN11, CXCL10, CXCL11 and TIMD4 were also found upregulated in endometrial explants from the ipsilateral uterine horn exposed to IFNT, a long, or a short day 15 conceptus (Sánchez et al. 2019). The same genes were upregulated on days 15, 17 and 18 in pregnant heifers compared to the respective non-pregnant controls (Bauersachs et al. 2012, Moraes et al. 2018) but not on 
days 12 and 13 (Forde et al. 2011, Bauersachs et al. 2012). The expression of these genes does not seem to be related with fertility since they were not differentially expressed between high-fertile and subfertile pregnant heifers (Moraes et al. 2018). Present results in the ipsilateral uterine horn combined with results from the aforementioned studies suggest that day 14 might be too early for those genes to be upregulated. Furthermore, differential expression of 185 genes only in the contralateral uterine horn and not in the ipsilateral may indicate a dysfunctional response to a conceptus which could be a consequence of an inadequate P4 priming, especially during the first days after ovulation (Takahashi et al. 2016).

Among the top ten downregulated genes from the 185 unique to the contralateral uterine horn were chromosome 15 open reading frame, human C11 orf34 (C15H11orf34), AQP3 and CFTR. C15H11orf34, also known as Placenta Expressed Transcript 1 (PLET1), has been reported to mark distinct populations of progenitor cells in several tissues and to provide essential cues to direct trophoblast stem cell differentiation (Murray et al. 2016). Forde et al. (2009) examined how elevated P4 from day 3 to day 7 , which has been associated with increased pregnancy success in cattle, affected the endometrial transcriptome. In this study, C15H11orf34 was found to be upregulated on day 16 of pregnancy in the endometrium of pregnant heifers with high compared with normal P4 concentrations. Moreover, in the study of Moraes et al. (2018), it was also upregulated on day 17 of pregnancy in high-fertile and subfertile heifers compared to its respective controls and expression was significantly higher in pregnant high-fertile compared to pregnant subfertile animals.

One of the functions of AQP3 and CFTR is water transport. In the pig, AQP1 and AQP5 may play an important role in maintaining local fluid balance within the uterus and embryo-maternal communication during implantation (Skowronska et al. 2016). Hayashi et al. (2017) found that AQP2 and AQP5 were upregulated in the ipsilateral horn endometrium of non-repeat breeder compared to repeat breeder cows. In agreement with our results, CFTR was one of the top ten down-regulated genes in the contralateral horn endometrium of repeat breeder cows (Hayashi et al. 2017). As mentioned earlier, CFTR is also involved in the maintenance of the ULF $\mathrm{pH}$. Defects in the regulation of these genes may lead to disturbance of the fluid microenvironment resulting in fertility problems.

Regarding the GO analysis of the 239 DEGs between CONTRA-D14 and CONTRA-CTRL, 50 of the 87 enriched BP were exclusive to the contralateral endometrium (Supplementary dataset 5). Among those with a highest enrichment fold were many related with response to and production of type I IFNs (alpha and beta) and type II IFN, IFNG. Type I IFNs are primarily induced by viral infection but can also be secreted in response to a variety of biological stresses, such as inflammation (Huber \& Farrar 2011). Some of the functions of type I IFNs are to modulate innate immune responses in a balanced manner and to activate the adaptive immune system (reviewed by Ivashkiv \& Donlin 2014). Although IFNA is similar to IFNT and has similar biological activity (Green et al. 2005, Bauersachs et al. 2012), administration of IFNA to heifers on day 13 after insemination decreased pregnancy rates by day 42 (Barros et al. 1992).

IFNG plays important roles in diverse cellular processes, including activating innate and adaptive immune responses, inhibiting cell proliferation and inducing apoptosis (reviewed by Murphy et al. 2009). High circulating levels of IFNG have been associated with pregnancy loss in humans (Mueller-Eckhardt et al. 1994, Jenkins et al. 2000), mice (Haddad et al. 1997) and pigs (Tayade et al. 2006). In pigs, IFNG elevation was strongly implicated in peri-implantation losses (Tayade et al. 2006, Murphy et al. 2009). Therefore, an excess production of both IFNA and IFNG, as might be the case in the contralateral uterine horn, could be detrimental for embryo development and/or successful pregnancy establishment.

\section{Direct comparison IPSILATERAL vs CONTRALATERAL}

The direct comparison between the IPSI-D14 and CONTRA-D14 revealed 32 DEGs (25 upregulated, 7 downregulated), in contrast with the 54 genes that were commonly upregulated when compared with their respective controls (Fig. 2). This apparent discrepancy likely arises due to the variation of expression within each group which will have an effect on the multiple correction of raw $P$ values to determine the FDR, based on which a gene is declared significant or not (Sánchez et al. 2019).

At least 22 of the 25 upregulated genes in CONTRA-D14 relative to IPSI-D14 are ISGs (Supplementary Table 3), which further demonstrates that the endometrium from the ipsilateral and contralateral uterine horns respond differently to IFNs. Type I IFNs can lead to immune cell recruitment and activation (Makris et al. 2017); therefore, an exacerbated response to type I IFNs, as observed in the contralateral uterine horn in our study, could increase the risk of tissue rejection and pregnancy loss (Ribeiro et al. 2016).

S100A2, CST6 and LBP were three of the seven downregulated genes in CONTRA-D14 relative to IPSI-D14 (i.e. were upregulated in IPSI-D14 relative to CONTRA-D14). In agreement with our results, S100A2 and $\angle B P$ were upregulated on day 15 of pregnancy compared to day 15 cyclic heifers (Bauersachs et al. 2012). S100A2 is part of the $S 100$ protein family which are involved in virtually all normal and pathological cell functions including cell proliferation, $\mathrm{Ca} 2+$ homeostasis, inflammatory and immune responses (Carafoli 2002, Berridge et al. 2003, Leclerc \& Heizmann 2011, Fleming 
et al. 2012). LBP encodes a protein that binds bacterial endotoxin (Schumann et al. 1996). Increased expression of antimicrobial genes in pregnant animals may confer innate immune protection against potential bacterial infection during a time of local immune suppression, as occurs during pregnancy (Walker et al. 2010). Forde et al. (2014a) found that CST6 was one of the most abundant proteins in the ULF during the pregnancy recognition period and hypothesized that it might be involved in driving conceptus elongation during the preimplantation period of pregnancy in cattle. Expression of cystatins and cathepsins in the uterine endometrium has been suggested to play important roles in endometrial remodeling during the reproductive cycle and pregnancy (Salamonsen 1999).

The most enriched BP in the GO analysis of the 32 DEGs between CONTRA-D14 and IPSI-D1 4 was positive regulation of Adenosine $3^{\prime}, 5^{\prime}$-cyclic monophosphate (CAMP)-mediated signaling with over 100-foldenrichment (GO:0043950). cAMP is a nucleotide that acts as a key second messenger in numerous signal transduction pathways, converting and amplifying extracellular signals (first messengers) (Yan et al. 2016). The enrichment of this and five other BP associated to response to stimulus might point to a different capacity of the endometrium of the contralateral and ipsilateral uterine horns to respond to extracellular signals produced by the conceptus.

The other four BP are related to immune response and cytokine production. Deregulation of the immune response may be partly responsible for the large number of pregnancy losses that occur during the implantation time (Walker etal.2010). In human, exaggerated maternal immune response to the fetus has been suggested as one of the underlying causes of a proportion of idiopathic recurrent pregnancy loss (Babbage et al. 2001, Saini et al. 2011).

The large difference in the number of DEGs between the endometrium ipsilateral and contralateral to the $\mathrm{CL}$ in response to a day 14 conceptus may be related to the differences in $\mathrm{P} 4$ concentrations during the first few days after ovulation (Takahashi et al. 2016), since P4 is one the majors regulators of the uterine receptivity through changes induced in the endometrium transcriptome (Spencer \& Bazer 1995, Forde \& Lonergan 2012, Brooks et al. 2014). In cattle, unlike twin- or litterbearing species, the presence of conceptus tissue is not expected in the contralateral uterine horn until day $18-19$, when the filamentous conceptus occupies both horns. Therefore, the precocious presence of a conceptus on day 14 may provoke an exaggerated response, particularly immune-related, that may cause problems later during the implantation period and lead to a pregnancy loss. Furthermore, differential expression of genes related to homeostasis suggest that the environment in the contralateral uterine horn may not be favorable for embryo development.

\section{Conclusion}

In conclusion, we report here the differential conceptusinduced transcriptomic response of bovine endometrium ipsilateral and contralateral to the CL. The response of the endometrium to a day 14 conceptus was distinct in each uterine horn with many of the biological processes enriched in the DEGs between CONTRA-D14 and IPSI-D14 being associated with immune response and response to stimuli. Knowledge generated in this and other such studies contribute to our knowledge of maternal embryo communication during this critical period and our understanding of the factors affecting embryonic loss.

\section{Supplementary materials}

This is linked to the online version of the paper at https://doi. org/10.1530/REP-19-0464.

\section{Declaration of interest}

Trudee Fair is on the editorial board of Reproduction. Trudee Fair was not involved in the review or editorial process for this paper, on which she is listed as an author. The other authors have nothing to disclose.

\section{Funding}

This work was supported by EU, Horizon 2020 Marie Sklodowska-Curie, REPBIOTECH 675526 and Science Foundation Ireland 13/IA/1983.

\section{Author contribution statement}

$\mathrm{P} L$, J M S and T F conceived the study. S B A, J M S, B F F, M $M$ and $P L$ performed the experiment. $S$ B A performed the lab work and analyzed the data. S K B and T E S performed the RNA sequencing and analyzed the data. S B A and P L wrote the manuscript. All authors discussed the results and contributed to the manuscript.

\section{Acknowledgements}

The authors thank the farm staff at UCD Lyons Research Farm for their help with the heifer's husbandry. The authors acknowledge the excellent help of numerous colleagues, especially Mary Wade, Clio Maicas, Dr Claudia Passaro, Dr Constantine Simintiras and Dr John A Browne.

\section{References}

Alberts B, Johnson A, Lewis J, Raff M, Roberts K \& Walter P 2002 Helper T cells and lymphocyte activation. In Molecular Biology of the Cell, 4th ed. New York: Garland Publishing Science.

Amirchaghmaghi E, Taghavi SA, Shapouri F, Saeidi S, Rezaei A \& Aflatoonian R 2013 The role of toll like receptors in pregnancy. International Journal of Fertility and Sterility 7 147-154. 
Ashworth CJ, Sales DI \& Wilmut I 1989 Evidence of an association between the survival of embryos and the periovulatory plasma progesterone concentration in the ewe. Journal of Reproduction and Fertility $\mathbf{8 7}$ 23-32. (https://doi.org/10.1530/jrf.0.0870023)

Babbage SJ, Arkwright PD, Vince GS, Perrey C, Pravica V, Quenby S, Bates M \& Hutchinson IV 2001 Cytokine promoter gene polymorphisms and idiopathic recurrent pregnancy loss. Journal of Reproductive Immunology 51 21-27. (https://doi.org/10.1016/s0165-0378(01)00069-9)

Barnwell C V., Farin PW, Ashwell CM, Farmer WT, Galphin SP \& Farin CE 2016 Differences in mRNA populations of short and long bovine conceptuses on day 15 of gestation. Molecular Reproduction and Development 83 424-441. (https://doi.org/10.1002/mrd.22640)

Barros CM, Newton GR, Thatcher WW, Drost M, Plante C \& Hansen PJ 1992 The effect of bovine interferon- $\alpha 11$ on pregnancy rate in heifers. Journal of Animal Science 70 1471-1477. (https://doi. org/10.2527/1992.7051471x)

Bauersachs S, Ulbrich SE, Zakhartchenko V, Minten M, Reichenbach M, Reichenbach H-DH-DD, Blum H, Spencer TE \& Wolf E 2009 The endometrium responds differently to cloned versus fertilized embryos. PNAS 106 5681-5686. (https://doi.org/10.1073/pnas.0811841106)

Bauersachs S, Ulbrich SE, Reichenbach H-D, Reichenbach M, Büttner M, Meyer HH, Spencer TE, Minten M, Sax G, Winter G et al. 2012 Comparison of the effects of early pregnancy with human interferon, alpha 2 (IFNA2), on gene expression in bovine endometrium. Biology of Reproduction 86 46. (https://doi.org/10.1095/biolreprod.111.094771)

Berridge MJ, Bootman MD \& Roderick HL 2003 Calcium signalling: dynamics, homeostasis and remodelling. Nature Reviews: Molecular Cell Biology 4 517-529. (https://doi.org/10.1038/nrm1155)

Bolger AM, Lohse M \& Usadel B 2014 Trimmomatic: a flexible trimmer for Illumina sequence data. Bioinformatics 30 2114-2120. (https://doi. org/10.1093/bioinformatics/btu170)

Borges ÁAM, Healey GD \& Sheldon IM 2012 Explants of intact endometrium to model bovine innate immunity and inflammation ex vivo. American Journal of Reproductive Immunology 67 526-539. (https://doi.org/10.1111/j.1600-0897.2012.01106.x)

Brooks K, Burns G \& Spencer TE 2014 Conceptus elongation in ruminants: roles of progesterone, prostaglandin, interferon tau and cortisol. Journal of Animal Science and Biotechnology 5 53. (https://doi.org/10.1186/20491891-5-53)

Carafoli E 2002 Calcium signaling: a tale for all seasons. PNAS 99 1115-1122. (https://doi.org/10.1073/pnas.032427999)

Carter F, Forde N, Duffy P, Wade M, Fair T, Crowe MA, Evans ACO, Kenny DA, Roche JF \& Lonergan P 2008 Effect of increasing progesterone concentration from day 3 of pregnancy on subsequent embryo survival and development in beef heifers. Reproduction, Fertility, and Development 20 368-375. (https://doi.org/10.1071/rd07204)

Christie WB, Newcomb R \& Rowson LE 1979 Embryo survival in heifers after transfer of an egg to the uterine horn contralateral to the corpus luteum and the effect of treatments with progesterone or hCG on pregnancy rates. Journal of Reproduction and Fertility 56 701-706. (https://doi.org/10.1530/jrf.0.0560701)

Dahlen CR, DiCostanzo A, Spell AR \& Lamb GC 2012 Use of embryo transfer seven days after artificial insemination or transferring identical demi-embryos to increase twinning in beef cattle. Journal of Animal Science 90 4823-4832. (https://doi.org/10.2527/jas.2011-4778)

Del Campo MR, Rowe RF, Chaichareon D \& Ginther OJ 1983 Effect of the relative locations of embryo and corpus luteum on embryo survival in cattle. Reproduction, Nutrition, Developpement 23 303-308. (https:// doi.org/10.1051/rnd:19830214)

Diskin MG, Murphy JJ \& Sreenan JM 2006 Embryo survival in dairy cows managed under pastoral conditions. Animal Reproduction Science 96 297-311. (https://doi.org/10.1016/j.anireprosci.2006.08.008)

Dominguez F, Galan A, Luna Martin JJ, Remohi J, Pellicer A \& Simón C 2003 Hormonal and embryonic regulation of chemokine receptors CXCR1, CXCR4, CCR5, and CCR2B in the human endometrium and the human blastocyst. Molecular Human Reproduction 9 189-198. (https:// doi.org/10.1093/molehr/gag024)

Echternkamp SE \& Gregory KE 2002 Reproductive, growth, feedlot, and carcass traits of twin vs single births in cattle. Journal of Animal Science 80 (E-Supplement_2) 1-10. (https://doi.org/10.2527/animalsci2002.80ESuppl_21b)
Fleming A \& Copp AJ 1998 Embryonic folate metabolism and mouse neural tube defects. Science 280 2107-2109. (https://doi.org/10.1126/ science.280.5372.2107)

Fleming JM, Ginsburg E, Oliver SD, Goldsmith P and\& Vonderhaar BK 2012 Hornerin, an S100 family protein, is functional in breast cells and aberrantly expressed in breast cancer. BMC Cancer 12 266. (https://doi. org/10.1186/1471-2407-12-266)

Forde N \& Lonergan P 2012 Transcriptomic analysis of the bovine endometrium: what is required to establish uterine receptivity to implantation in cattle? Journal of Reproduction and Development 58 189-195. (https://doi.org/10.1262/jrd.2011-021)

Forde N, Carter F, Fair T, Crowe MA, Evans ACO, Spencer TE, Bazer FW, McBride R, Boland MP, O'Gaora P et al. 2009 Progesterone-regulated changes in endometrial gene expression contribute to advanced conceptus development in cattle. Biology of Reproduction 81 784-794. (https://doi.org/10.1095/biolreprod.108.074336)

Forde N, Carter F, Spencer TE, Bazer FW, Sandra O, Mansouri-Attia N, Okumu LA, McGettigan PA, Mehta JP, McBride R et al. 2011 Conceptusinduced changes in the endometrial transcriptome: how soon does the cow know she is pregnant?. Biology of Reproduction 85 144-156. (https://doi.org/10.1095/biolreprod.110.090019)

Forde N, Mehta JP, Minten M, Crowe MA, Roche JF, Spencer TE \& Lonergan P 2012 Effects of low progesterone on the endometrial transcriptome in cattle. Biology of Reproduction 87 124. (https://doi. org/10.1095/biolreprod.112.103424)

Forde N, Simintiras CA, Sturmey R, Mamo S, Kelly AK, Spencer TE, Bazer FW \& Lonergan P 2014a Amino acids in the uterine luminal fluid reflects the temporal changes in transporter expression in the endometrium and conceptus during early pregnancy in cattle. PLOS ONE 9 e100010. (https://doi.org/10.1371/journal.pone.0100010)

Forde N, McGettigan PA, Mehta JP, O'Hara L, Mamo S, Bazer FW, Spencer TE \& Lonergan P $2014 b$ Proteomic analysis of uterine fluid during the pre-implantation period of pregnancy in cattle. Reproduction 147 575-587. (https://doi.org/10.1530/REP-13-0010)

Fricke PM \& Wiltbank MC 1999 Effect of milk production on the incidence of double ovulation in dairy cows. Theriogenology 52 1133-1143. (https://doi.org/10.1016/S0093-691X(99)00205-8)

Gao H, Wu G, Spencer TE, Johnson GA, Li X \& Bazer FW 2009 Select nutrients in the ovine uterine lumen. I. Amino acids, glucose, and ions in uterine lumenal flushings of cyclic and pregnant ewes. Biology of Reproduction 80 86-93. (https://doi.org/10.1095/biolreprod.108.071597)

Garcia-Ispierto I \& López-Gatius F 2019 Abortion in dairy cattle with advanced twin pregnancies: incidence and timing. Reproduction in Domestic Animals 54 (Supplement 4) 50-53. (https://doi.org/10.1111/ rda.13510)

Gray CA 2005 Identification of Endometrial Genes Important for Conceptus Survival and Development in Sheep. Texas: A\&M University.

Green MP, Spate LD, Bixby JA, Ealy AD \& Roberts RM 2005 A comparison of the anti-luteolytic activities of recombinant ovine interferon-alpha and -tau in sheep. Biology of Reproduction 73 1087-1093. (https://doi. org/10.1095/biolreprod.105.043406)

Groebner AE, Rubio-Aliaga I, Schulke K, Reichenbach HD, Daniel H, Wolf E, Meyer HH \& Ulbrich SE 2011 Increase of essential amino acids in the bovine uterine lumen during preimplantation development. Reproduction 141 685-695. (https://doi.org/10.1530/REP-10-0533)

Guerra-Martinez P, Dickerson GE, Anderson GB \& Green RD 1990 Embryo-transfer twinning and performance efficiency in beef production. Journal of Animal Science 68 4039-4050. (https://doi. org/10.2527/1990.68124039x)

Haddad EK, Duclos AJ, Antecka E, Lapp WS \& Baines MG 1997 Role of interferon-gamma in the priming of decidual macrophages for nitric oxide production and early pregnancy loss. Cellular Immunology 181 68-75. (https://doi.org/10.1006/cimm.1997.1199)

Hayashi KG, Hosoe M, Kizaki K, Fujii S, Kanahara H, Takahashi T \& Sakumoto R 2017 Differential gene expression profiling of endometrium during the mid-luteal phase of the estrous cycle between a repeat breeder (RB) and non-RB cows. Reproductive Biology and Endocrinology 1520. (https://doi.org/10.1186/s12958-017-0237-6)

Heinrich PC, Castell J V \& Andus T 1990 Interleukin-6 and the acute phase response. Biochemical Journal 265 621-636. (https://doi.org/10.1042/ bj2650621) 
Hellemans J, Mortier G, De Paepe A, Speleman F \& Vandesompele J 2008 qBase relative quantification framework and software for management and automated analysis of real-time quantitative PCR data. Genome Biology 8 R19. (https://doi.org/10.1186/gb-2007-8-2-r19)

Huber JP \& Farrar JD 2011 Regulation of effector and memory T-cell functions by type I interferon. Immunology 132 466-474. (https://doi. org/10.1111/j.1365-2567.2011.03412.x)

Imakawa K, Imai M, Sakai A, Suzuki M, Nagaoka K, Sakai S, Lee SR, Chang KT, Echternkamp SE \& Christenson RK 2006 Regulation of conceptus adhesion by endometrial CXC chemokines during the implantation period in sheep. Molecular Reproduction and Development 73 850-858. (https://doi.org/10.1002/mrd.20496)

Ivashkiv LB \& Donlin LT 2014 Regulation of type I interferon responses. Nature Reviews: Immunology 14 36-49. (https://doi.org/10.1038/ nri3581)

Izaike Y, Suzuki O, Shimada K, Fujita K \& Kosugiyama M 1988 Twin pregnancy diagnosis and early embryonic loss after bilateral egg transfer in beef cattle. Japanese Journal of Animal Reproduction 34 236-242. (https://doi.org/10.1262/jrd1977.34.236)

Janeway CA Jr \& Medzhitov R 2002 Innate immune recognition. Annual Review of Immunology 20 197-216. (https://doi.org/10.1146/annurev. immunol.20.083001.084359)

Jenkins C, Roberts J, Wilson R, MacLean MA, Shilito J \& Walker JJ 2000 Evidence of a $\mathrm{T}(\mathrm{H}) 1$ type response associated with recurrent miscarriage. Fertility and Sterility 73 1206-1208. (https://doi.org/10.1016/s00150282(00)00517-3)

Jones NL 2002 The Tim family: new players in the Th1/Th2 paradigm. Pediatric Research 52 1. (https://doi.org/10.1203/00006450-20020700000001)

Kim D, Langmead B \& Salzberg SL 2015 HISAT: a fast spliced aligner with low memory requirements. Nature Methods 12 357-360. (https://doi. org/10.1038/nmeth.3317)

Kimura A \& Kishimoto T 2010 IL-6: regulator of Treg/Th17 balance. European Journal of Immunology 40 1830-1835. (https://doi. org/10.1002/eji.201040391)

Leclerc E \& Heizmann CW 2011 The importance of Ca2+/Zn2+ signaling S100 proteins and RAGE in translational medicine. Frontiers in Bioscience 3 1232-1262. (https://doi.org/10.2741/223)

Liao Y, Smyth GK \& Shi W 2014 featureCounts: an efficient general purpose program for assigning sequence reads to genomic features. Bioinformatics 30 923-930. (https://doi.org/10.1093/bioinformatics/btt656)

Liu Y-X, Gao F, Wei P, Chen X-L, Gao H-J, Zou R-J, Siao L-J, Xu F-H, Feng Q, Liu K et al. 2005 Involvement of molecules related to angiogenesis, proteolysis and apoptosis in implantation in rhesus monkey and mouse. Contraception 71 249-262. (https://doi.org/10.1016/j. contraception.2004.12.008)

Lonergan P \& Forde N 2014 Maternal-embryo interaction leading up to the initiation of implantation of pregnancy in cattle. Animal 8 (Supplement 1) 64-69. (https://doi.org/10.1017/S1751731114000470)

Lonergan P, Forde N \& Spencer TE 2016 Role of progesterone in embryo development in cattle. Reproduction, Fertility, and Development $\mathbf{2 8}$ 66-74. (https://doi.org/10.1071/RD15326)

Makris S, Paulsen M \& Johansson C 2017 Type I interferons as regulators of lung inflammation. Frontiers in Immunology 8 259. (https://doi. org/10.3389/fimmu.2017.00259)

Mann GE \& Lamming GE 2001 Relationship between maternal endocrine environment, early embryo development and inhibition of the luteolytic mechanism in cows. Reproduction 121 175-180. (https://doi. org/10.1530/rep.0.1210175)

Mansouri-Attia N, Oliveira LJ, Forde N, Fahey AG, Browne JA, Roche JF, Sandra O, Reinaud P, Lonergan P \& Fair T 2012 Pivotal role for monocytes/macrophages and dendritic cells in maternal immune response to the developing embryo in cattle. Biology of Reproduction $\mathbf{8 7}$ 123. (https://doi.org/10.1095/biolreprod.112.101121)

Mansouri-Attia N, Sandra O, Aubert J, Degrelle S, Everts RE, GiraudDelville C, Heyman Y, Galio L, Hue I, Yang X et al. 2009 Endometrium as an early sensor of in vitro embryo manipulation technologies. PNAS 106 5687-5692. (https://doi.org/10.1073/pnas.0812722106)

Mathew DJ, Sánchez JM, Passaro C, Charpigny G, Behura SK, Spencer TE \& Lonergan P 2018 Interferon tau-dependent and independent effects of the bovine conceptus on the endometrial transcriptome. Biology of Reproduction 100 365-380. (https://doi.org/10.1093/biolre/ioy199)
McMillan WH \& Peterson AJ 1995 Evidence for a high frequency of embryo migration in cattle after uni-lateral twin embryo transfer. Theriogenology 43 278. (https://doi.org/10.1016/0093-691X(95)92432-9)

McMillan WH \& Peterson AJ 1999 Transuterine embryo migration in recipient cattle. Theriogenology 51 1577-1586. (https://doi.org/10.1016/ s0093-691x(99)00100-4)

McNeill RE, Diskin MG, Sreenan JM \& Morris DG 2006 Associations between milk progesterone concentration on different days and with embryo survival during the early luteal phase in dairy cows. Theriogenology 65 1435-1441. (https://doi.org/10.1016/j. theriogenology.2005.08.015)

Moraes JGN, Behura SK, Geary TW, Hansen PJ, Neibergs HL \& Spencer TE 2018 Uterine influences on conceptus development in fertilityclassified animals. PNAS 115 E1749-E1758. (https://doi.org/10.1073/ pnas.1721191115)

Mueller-Eckhardt G, Mallmann P, Neppert J, Lattermann A, Melk A, Heine O, Pfeiffer R, Zingsem J, Domke N \& Mohr-Pennert A 1994 Immunogenetic and serological investigations in nonpregnant and in pregnant women with a history of recurrent spontaneous abortions. German RSA/IVIG Study Group. Journal of Reproductive Immunology 27 95-109. (https://doi.org/10.1016/0165-0378(94)90026-4)

Murphy SP, Tayade C, Ashkar AA, Hatta K, Zhang J \& Croy BA 2009 Interferon gamma in successful pregnancies. Biology of Reproduction 80 848-859. (https://doi.org/10.1095/biolreprod.108.073353)

Murray A, Sienerth AR \& Hemberger M 2016 Plet1 is an epigenetically regulated cell surface protein that provides essential cues to direct trophoblast stem cell differentiation. Scientific Reports 6 25112. (https:// doi.org/10.1038/srep25112)

Nagaoka K, Nojima H, Watanabe F, Chang KT, Christenson RK, Sakai S \& Imakawa K 2003 Regulation of blastocyst migration, apposition, and initial adhesion by a chemokine, interferon $\gamma$-inducible protein 10 kDa (IP-10), during early gestation. Journal of Biological Chemistry 278 29048-29056. (https://doi.org/10.1074/jbc.M300470200)

Ohana E, Yang D, Shcheynikov N \& Muallem S 2009 Diverse transport modes by the solute carrier 26 family of anion transporters. Journal of Physiology 587 2179-2185. (https://doi.org/10.1113/jphysiol.2008.164863)

Okamura-lkeda K, Hosaka H, Maita N, Fujiwara K, Yoshizawa AC, Nakagawa A \& Taniguchi H 2010 Crystal structure of aminomethyltransferase in complex with dihydrolipoyl-H-protein of the glycine cleavage system: implications for recognition of lipoyl protein substrate, disease-related mutations, and reaction mechanism. Journal of Biological Chemistry 285 18684-18692. (https://doi.org/10.1074/jbc. M110.110718)

Okano A, Ogawa H, Takahashi H \& Geshi M 2007 Apoptosis in the porcine uterine endometrium during the estrous cycle, early pregnancy and post partum. Journal of Reproduction and Development 53 923-930. (https:// doi.org/10.1262/jrd.18139)

Oliveira LJ, Mansouri-Attia N, Fahey AG, Browne J, Forde N, Roche JF, Lonergan P \& Fair T 2013 Characterization of the Th profile of the bovine endometrium during the oestrous cycle and early pregnancy. PLOS ONE 8 e75571. (https://doi.org/10.1371/journal.pone.0075571)

Passaro C, Tutt D, Mathew DJ, Sanchez JM, Browne JA, Boe-Hansen GB, Fair T \& Lonergan P 2018 Blastocyst-induced changes in the bovine endometrial transcriptome. Reproduction 156 219-229. (https://doi. org/10.1530/REP-18-0188)

Passaro C, Tutt D, Bagés-Arnal S, Maicas C, Laguna-Barraza R, GutierrezAdán A, Browne JA, Rath D, Behura SK, Spencer TE et al. 2019 Global transcriptomic response of bovine endometrium to blastocyst-stage embryos. Reproduction 158 223-235. (https://doi.org/10.1530/REP-190064)

Prins JR, Gomez-Lopez N \& Robertson SA 2012 Interleukin-6 in pregnancy and gestational disorders. Journal of Reproductive Immunology 95 1-14. (https://doi.org/10.1016/j.jri.2012.05.004)

Randi F, McDonald M, Duffy P, Kelly AK \& Lonergan P 2018 The relationship between external auditory canal temperature and onset of estrus and ovulation in beef heifers. Theriogenology 110 175-181. (https://doi.org/10.1016/j.theriogenology.2018.01.001)

Red-Horse K, Drake PM, Gunn MD \& Fisher SJ 2001 Chemokine ligand and receptor expression in the pregnant uterus: reciprocal patterns in complementary cell subsets suggest functional roles. American Journal of Pathology 159 2199-2213. (https://doi.org/10.1016/S00029440(10)63071-4) 
Ribeiro ES, Gomes G, Greco LF, Cerri RLA, Vieira-Neto A, Monteiro PLJ, Lima FS, Bisinotto RS, Thatcher WW \& Santos JEP 2016 Carryover effect of postpartum inflammatory diseases on developmental biology and fertility in lactating dairy cows. Journal of Dairy Science 99 2201-2220. (https://doi.org/10.3168/jds.2015-10337)

Rizos D, Ward F, Duffy P, Boland MP \& Lonergan P 2002 Consequences of bovine oocyte maturation, fertilization or early embryo development in vitro versus in vivo: implications for blastocyst yield and blastocyst quality. Molecular Reproduction and Development 61 234-248. (https:// doi.org/10.1002/mrd.1153)

Robertson SA 2010 Immune regulation of conception and embryo implantation-all about quality control? Journal of Reproductive Immunology 85 51-57. (https://doi.org/10.1016/j.jri.2010.01.008)

Rowson LE, Lawson RA \& Moor RM 1971 Production of twins in cattle by egg transfer. Journal of Reproduction and Fertility 25 261-268. (https:// doi.org/10.1530/jrf.0.0250261)

Saini V, Arora S, Yadav A \& Bhattacharjee J 2011 Cytokines in recurrent pregnancy loss. Clinica Chimica Acta 412 702-708. (https://doi. org/10.1016/j.cca.2011.01.002)

Salamonsen LA 1999 Role of proteases in implantation. Reviews of Reproduction 4 11-22. (https://doi.org/10.1530/ror.0.0040011)

Sánchez JM, Passaro C, Forde N, Browne JA, Behura SK, FernándezFuertes B, Mathew DJ, Kelly AK, Butler ST, Spencer TE et al. 2018 Do differences in the endometrial transcriptome between uterine horns ipsilateral and contralateral to the corpus luteum influence conceptus growth to day 14 in cattle? Biology of Reproduction 100 86-100. (https:// doi.org/10.1093/biolre/ioy185)

Sánchez JM, Mathew DJ, Behura SK, Passaro C, Charpigny G, Butler ST, Spencer TE \& Lonergan P 2019 Bovine endometrium responds differentially to age-matched short and long conceptusest. Biology of Reproduction 101 26-39. (https://doi.org/10.1093/biolre/ioz060)

Scanlon PF 1972 Frequency of transuterine migration of embryos in ewes and cows. Journal of Animal Science 34 791-794. (https://doi. org/10.2527/jas1972.345791x)

Scheller J, Chalaris A, Schmidt-Arras D \& Rose-John S 2011 The proand anti-inflammatory properties of the cytokine interleukin-6. Biochimica et Biophysica Acta 1813 878-888. (https://doi.org/10.1016/j. bbamcr.2011.01.034)

Schumann RR, Kirschning CJ, Unbehaun A, Aberle HP, Knope HP, Lamping N, Ulevitch RJ \& Herrmann F 1996 The lipopolysaccharidebinding protein is a secretory class 1 acute-phase protein whose gene is transcriptionally activated by APRF/STAT/3 and other cytokine-inducible nuclear proteins. Molecular and Cellular Biology 16 3490-3503. (https:// doi.org/10.1128/mcb.16.7.3490)

Skowronska A, Mlotkowska P, Majewski M, Nielsen S \& Skowronski MT 2016 Expression of aquaporin 1 and 5 and their regulation by ovarian hormones, arachidonic acid, forskolin and cAMP during implantation in pigs. Physiological Research 65 637-650. (https://doi.org/10.33549/ physiolres.933095)

Spencer TE \& Bazer FW 1995 Temporal and spatial alterations in uterine estrogen receptor and progesterone receptor gene expression during the estrous cycle and early pregnancy in the ewe. Biology of Reproduction 53 1527-1543. (https://doi.org/10.1095/biolreprod53.6.1527)

Spencer TE, Forde N \& Lonergan P 2016 The role of progesterone and conceptus-derived factors in uterine biology during early pregnancy in ruminants. Journal of Dairy Science 99 5941-5950. (https://doi. org/10.3168/jds.2015-10070)

Sreenan JM \& Diskin MG 1989 Effect of a unilateral or bilateral twin embryo distribution on twinning and embryo survival rate in the cow. Journal of Reproduction and Fertility 87 657-664. (https://doi.org/10.1530/ jrf.0.0870657)

Sreenan JM, Diskin MG \& McDonagh T 1981 Induction of twin-calving by non-surgical embryo transfer: a field trial. Veterinary Record 109 77-80. (https://doi.org/10.1136/vr.109.4.77)

Stronge AJH, Sreenan JM, Diskin MG, Mee JF, Kenny DA \& Morris DG 2005 Post-insemination milk progesterone concentration and embryo survival in dairy cows. Theriogenology 64 1212-1224. (https://doi. org/10.1016/j.theriogenology.2005.02.007)

Suzuki T, Sakumoto R, Hayashi KG, Ogiso T, Kunii H, Shirozu T, Kim SW, Bai H, Kawahara M, Kimura K et al. 2018 Involvement of interferon-tau in the induction of apoptotic, pyroptotic, and autophagic cell deathrelated signaling pathways in the bovine uterine endometrium during early pregnancy. Journal of Reproduction and Development $\mathbf{6 4}$ 495-502. (https://doi.org/10.1262/jrd.2018-063)

Takahashi H, Haneda S, Kayano M \& Matsui M 2016 Differences in progesterone concentrations and mRNA expressions of progesterone receptors in bovine endometrial tissue between the uterine horns ipsilateral and contralateral to the corpus luteum. Journal of Veterinary Medical Science 78 613-618. (https://doi.org/10.1292/jvms.15-0366)

Tassell W, Slater M, Barden JA \& Murphy CR 2000 Endometrial cell death during early pregnancy in the rat. Histochemical Journal 32 373-379. (https://doi.org/10.1023/a:1004069731540)

Tayade C, Black GP, Fang Y \& Croy BA 2006 Differential gene expression in endometrium, endometrial lymphocytes, and trophoblasts during successful and abortive embryo implantation. Journal of Immunology 176 148-156. (https://doi.org/10.4049/jimmunol.176.1.148)

Umetsu SE, Lee WL, McIntire JJ, Downey L, Sanjanwala B, Akbari O, Berry GJ, Nagumo H, Freeman GJ, Umetsu DT et al. 2005 TIM-1 induces T cell activation and inhibits the development of peripheral tolerance. Nature Immunology 6 447-454. (https://doi.org/10.1038/ni1186)

Valenza A, Giordano JO, Lopes G, Vincenti L, Amundson MC \& Fricke PM 2012 Assessment of an accelerometer system for detection of estrus and treatment with gonadotropin-releasing hormone at the time of insemination in lactating dairy cows. Journal of Dairy Science 95 7115-7127. (https://doi.org/10.3168/jds.2012-5639)

Vandesompele J, De Preter K, Pattyn F, Poppe B, Van Roy N, De Paepe A \& Speleman F 2002 Accurate normalization of real-time quantitative RT-PCR data by geometric averaging of multiple internal control genes. Genome Biology 3 RESEARCH0034. (https://doi.org/10.1186/gb-20023-7-research0034)

Walker WL, Nebel RL \& McGilliard ML 1996 Time of ovulation relative to mounting activity in dairy cattle. Journal of Dairy Science $\mathbf{7 9}$ 1555-1561. (https://doi.org/10.3168/jds.S0022-0302(96)76517-7)

Walker CG, Meier S, Littlejohn MD, Lehnert K, Roche JR \& Mitchell MD 2010 Modulation of the maternal immune system by the pre-implantation embryo. BMC Genomics 11 474. (https://doi.org/10.1186/1471-216411-474)

Weems CW, Lee CN, Weems YS \& Vincent DL 1988 Distribution of progesterone to the uterus and associated vasculature of cattle. Endocrinologia Japonica 35 625-630. (https://doi.org/10.1507/ endocrj1954.35.625)

Wiltbank MC, Souza AH, Carvalho PD, Cunha AP, Giordano JO, Fricke PM, Baez GM \& Diskin MG 2014 Physiological and practical effects of progesterone on reproduction in dairy cattle. Animal 8 (Supplement 1) 70-81. (https://doi.org/10.1017/S1751731114000585)

Xie ZD, Guo YM, Ren MJ, Yang J, Wang SF, Xu TH, Chen LM \& Liu Y 2018 The balance of $\mathrm{HCO} 3$ - secretion vs. reabsorption in the endometrial epithelium regulates uterine fluid $\mathrm{pH}$. Frontiers in Physiology 912. (https://doi.org/10.3389/fphys.2018.00012)

Yan K, Gao LN, Cui YL, Zhang Y \& Zhou X 2016 The cyclic AMP signaling pathway: exploring targets for successful drug discovery (Review). Molecular Medicine Reports 13 3715-3723. (https://doi.org/10.3892/ mmr.2016.5005)

Zhou X, Lindsay H \& Robinson MD 2014 Robustly detecting differential expression in RNA sequencing data using observation weights. Nucleic Acids Research 42 e91. (https://doi.org/10.1093/nar/gku310)

Zoppoli G, Regairaz M, Leo E, Reinhold WC, Varma S, Ballestrero A, Doroshow JH \& Pommier Y 2012 Putative DNA/RNA helicase Schlafen-11 (SLFN11) sensitizes cancer cells to DNA-damaging agents. PNAS 109 15030-15035. (https://doi.org/10.1073/pnas.1205943109)

Received 29 September 2019

First decision 1 November 2019

Revised manuscript received 3 March 2020

Accepted 12 March 2020 